\title{
ERINA OHARA
}

Caracterização da tolerância ao estresse oxidativo, capacidade de remoção de proteínas oxidadas e a expectativa de vida de linhagens da levedura $S$. cerevisiae com mutações sítio-específicas na subunidade $\alpha 5$ do proteassomo 20S: Implicações na prevenção de agregação proteica

Dissertação apresentada ao Programa de PósGraduação em Ciências Morfofuncionais do Instituto de Ciências Biomédicas da Universidade de São Paulo, para a obtenção do Título de Mestre em Ciências. 


\section{ERINA OHARA}

Caracterização da tolerância ao estresse oxidativo, capacidade de remoção de proteínas oxidadas e a expectativa de vida de linhagens da levedura $S$. cerevisiae com mutações sítio-específicas na subunidade $\alpha 5$ do proteassomo 20S: Implicações na prevenção de agregação proteica

Dissertação apresentada ao Programa de PósGraduação em Ciências Morfofuncionais do Instituto de Ciências Biomédicas da Universidade de São Paulo, para a obtenção do Título de Mestre em Ciências.

Área de Concentração: Ciências Morfofuncionais.

Orientador: Dra. Marilene Demasi.

Versão original 


\section{DADOS DE CATALOGAÇÃO NA PUBLICAÇÃO (CIP) \\ Serviço de Biblioteca e Informação Biomédica do}

Instituto de Ciências Biomédicas da Universidade de São Paulo

reprodução não autorizada pelo autor

Ohara, Erina.

Caracterização da tolerância ao estresse oxidativo, capacidade de remoção de proteínas oxidadas e a expectativa de vida de linhagens da levedura $S$. cerevisiae com mutações sítio-específicas na subunidade a5 do proteassomo 20S: Implicações na prevenção de agregação proteica / Erina Ohara. -- São Paulo, 2015.

Orientador: Profa. Dra. Marilene Demasi.

Dissertação (Mestrado) - Universidade de São Paulo. Instituto de Ciências Biomédicas. Departamento de Anatomia. Área de concentração: Ciências Morfofuncionais. Linha de pesquisa: Modulação redox do proteassomo 205.

Versão do título para o inglês: Characterization of tolerance to oxidative stress, capacity to remove oxidized proteins and the life span of the yeast $S$. cerevisiae with site-specific mutations in the a5 subunit of the 20 S proteasome: Implications in the prevention of protein aggregation.

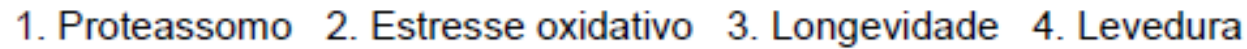
5. S-glutatiolação 6. Agregados I. Demasi,Profa. Dra. Marilene II. Universidade de São Paulo. Instituto de Ciências Biomédicas. Programa de Pós-Graduação em Ciências Morfofuncionais III. Título. 
Candidato(a):

Título da Dissertação:

Orientador(a):
Erina Ohara.

Caracterização da tolerância ao estresse oxidativo, capacidade de remoção de proteínas oxidadas e a expectativa de vida de linhagens da levedura S. cerevisiae com mutações sítio-específicas na subunidade a5 do proteassomo 20S: Implicações na prevenção de agregação proteica.

A Comissão Julgadora dos trabalhos de Defesa da Dissertação de Mestrado, em sessão pública realizada a .......... considerou

\title{
( ) Aprovado(a)
}

( ) Reprovado(a)

\author{
Examinador(a): Assinatura: \\ Nome: \\ Instituição: \\ Examinador(a): Assinatura: \\ Nome: \\ Instituição: \\ Presidente: Assinatura: \\ Nome: \\ Instituição:
}




\section{CERTIFICADO DE ISENÇÃO}

Certificamos que o Protocolo CEP-ICB N ${ }^{\circ}$ 592/13 referente ao projeto intitulado: "Caracterização da tolerência ao estresse oxidativo, capacidade de remoção de proteinas oxidadas e a expectativa de vida de linhagens da levedura S. cerevisiae com mutações sítio-específicas no proteassoma 20S: implicações na prevenção e agregação proteica" sob a responsabilidade de Erina Ohara, foi analisado na presente data pela CEUA - COMISSÃO DE ÉTICA NO USO DE ANIMAIS e pela CEPSHCOMISSÃo DE ÉtICA EM PESQUISA COM SERES HUMANOS, tendo sido deliberado que o referido projeto não utilizará animais que estejam sob a égide da lei 11.794 de 8 de outubro de 2008, nem envolverá procedimentos regulados pela Resolução CONEP n¹96 de 1996.

São Paulo, 26 de abril de 2013.

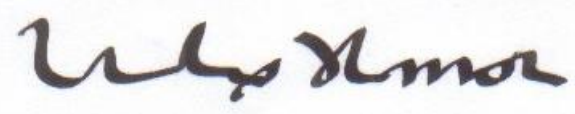

PROF. DR. WOTHAN TAVARES DE LIMA Coordenador da CEUA - ICB/USP

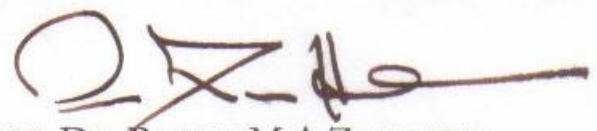

PROF. DR. PAOLO M.A ZaNOTTO Coordenador da CEPsh - ICB/USP 
Ao meu pai (in memoriam), que desde cedo me ensinou com muito carinho o valor do conhecimento. À minha mãe Satomi, ao meu marido Rodrigo e ao meu irmãozinho Mic, as pessoas mais importantes da minha vida. 


\section{AGRADECIMENTOS}

À Dra. Marilene Demasi, pela oportunidade, confiança, paciência e por todos os ensinamentos. Orgulho-me ter sido orientada por alguém de tamanha coerência, sabedoria e amor á ciência.

Ao Prof. Dr. Luis Eduardo Soares Netto pelo apoio, sugestões e disponibilização irrestrita de seu laboratório durante todo o desenvolvimento deste trabalho.

Ao Dr. Mário Henrique Barros que disponibilizou seu tempo e laboratório para construção das linhagens mutantes de levedura aqui estudadas.

Ao Dr. Daniel Carvalho Pimenta e seu aluno de doutorado Douglas Oscar Ceolin Mariano por todo auxílio e ajuda na identificação de proteínas por espectrometria de massa.

Ao Dr. Prof. Cristiano Luis Pinto de Oliveira e sua aluna de mestrado Renata Naporano Bicev pelas imagens do proteassomo por microscopia eletrônica de transmissão.

Aos colegas do Laboratório do prof. Luis Eduardo Soares Netto, principalmente o Fernando Gomes, uma das pessoas mais prestativas que conheci em minha vida, agradeço muito por todo seu apoio.

Às meninas do laboratório, Janaina Leme e Vanessa Ramalho, pelo apoio, incentivo, discussões, risadas, fofocas, proteassomo purificado... Obrigada pelas suas amizades e por tornar os meus dias de trabalho mais agradáveis.

Ao ex-técnico do laboratório Adrian, uma pessoa muito competente e sempre prestativa. Zen, filósofo e metódico, eu não poderia ter aprendido as técnicas utilizadas no laboratório com uma pessoa melhor.

À Capes pelo indispensável auxílio financeiro para realização deste trabalho.

À Deus, por sua constante presença, amor e cuidado em todos os mementos da minha existência. Sou muito grata pela maravilhosa vida concedida e por propiciar o convívio com pessoas tão iluminadas e especiais.

Aos meus queridos amigos, espalhados por todos os cantos, que sempre me deram força e torceram para que eu pudesse conquistar mais essa vitória.

Aos meus pais Iwao Ohara (in memoriam) e Satomi Ohara, que conhecem o melhor e o pior de mim, que estiveram ao meu lado nos momentos mais difíceis e alegres, que continuarão me amando mesmo com todos os meus defeitos. Obrigada pelo amor e apoio incondicional e por me oferecerem as condições necessárias para a minha formação pessoal e profissional.

Ao meu irmãozinho Michael Ohara, que mesmo não entendendo absolutamente nada, me ajudou a ensaiar os seminários apresentados durante o mestrado. 
Por ultimo, o meu mais profundo agradecimento ao meu marido, Rodrigo, meu porto seguro. Sempre ao meu lado, me incentivando e apoiando. Nos momentos mais difíceis, que não foram raros neste período, o tempo todo me fazendo acreditar que chegaria ao final com êxito. Sou muito grata por cada gesto de carinho, cada sorriso, e pelo constante amor. 
"Quando abro a porta de uma nova descoberta já encontro Deus lá dentro"

- Albert Einstein 


\section{RESUMO}

OHARA, E. Caracterização da tolerância ao estresse oxidativo, capacidade de remoção de proteínas oxidadas e a expectativa de vida de linhagens da levedura $S$. cerevisiae com mutações sítio-específicas na subunidade a5 do proteassomo 20S: Implicações na prevenção de agregação proteica. 201574 f. Dissertação (Mestrado em Ciências Morfofuncionais) - Instituto de Ciências Biomédicas, Universidade de São Paulo, 2015.

O proteassomo é um complexo proteico responsável pela degradação de proteínas poliubiquitinadas. É constituído por uma unidade catalítica denominada de proteassomo $20 \mathrm{~S}$ (20SPT) e por unidades regulatórias (19S) acopladas em uma ou ambas as extremidades para formar o proteassomo 26S. O 20SPT é capaz de degradar proteínas por um processo independente de ATP e ubiquitina. Este mecanismo é considerado preventivo de agregação proteica, uma vez que o acúmulo de proteínas oxidadas está diretamente associado ao envelhecimento e doenças neurodegenerativas. Foi observado pelo grupo que o 20SPT da levedura S.cerevisiae sofre S-glutatiolação nos resíduos de Cys 76 e Cys 221 da subunidade a5. Dados obtidos por microscopia eletrônica de transmissão mostraram que a S-glutatiolação promove a abertura da câmara catalítica e consequentemente o aumento da degradação de proteínas. Recentemente, foram obtidas linhagens com mutações sítio-específicas pela substituição dos dois resíduos de Cys glutatioláveis por Ser. Ensaios realizados com a linhagem C221 mostraram um aumento da longevidade e resistência ao estresse oxidativo quando comparada com a linhagem selvagem, enquanto que a linhagem C76 mostrou uma dificuldade no crescimento. Foi verificado também que a população de proteassomo isolada da linhagem C221 apresenta maior proporção da forma aberta da câmara catalítica. Resultados opostos foram observados na linhagem C76. No entanto, constatamos um aumento de proteínas oxidadas e de agregados proteicos na linhagem C221 em comparação a selvagem. Esses dados não condizem com o aumento do tempo de vida cronológico desta linhagem, porém, acreditamos que esses agregados estejam relacionados a um tipo de "sequestro" de proteínas potencialmente prejudiciais, como será discutido neste trabalho.

Palavras-chave: Proteassomo. Estresse oxidativo. Longevidade. S-glutatiolação. Agregados. 


\begin{abstract}
ABTRACT
OHARA, E. Characterization of tolerance to oxidative stress, capacity to remove oxidized proteins and the life span of the yeast $S$. cerevisiae with site-specific mutations in the $\alpha 5$ subunit of the $20 \mathrm{~S}$ proteasome: Implications in the prevention of protein aggregation. 201574 p. Master thesis (Morphofunctional Sciences) - Instituto de Ciências Biomédicas, Universidade de São Paulo, 2015.
\end{abstract}

The proteasome is a protein complex responsible for the degradation of poly-ubiquitinated proteins. It comprises a catalytic unit called $20 \mathrm{~S}$ proteasome (20SPT) and regulatory units (19S) coupled at one or both ends to form the 26S proteasome. The 20SPT is able to degrade proteins by an ATP and ubiquitin independent process. This mechanism is considered preventive of protein aggregation, since the accumulation of oxidized proteins is directly related to aging and neurodegenerative diseases. It was observed by our group that the yeast 20SPT (S. cerevisiae) is modified by S-glutathiolation in the residues Cys 76 and Cys 221 of the $\alpha 5$ subunit. Data obtained by transmission electron microscopy showed that the Sglutathiolation promotes the opening of the catalytic chamber and consequently increased degradation of oxidized proteins. Recently, strains were obtained by site-specific mutations by replacing the two glutathiolable Cys residues by Ser. Tests performed with the C221 strain showed an increased longevity and resistance to oxidative stress when compared to the wild type strain, whereas the C76 strain showed a slower growth. It was also found that the isolated population of the $\alpha 5-\mathrm{C} 221 \mathrm{~S}$ proteasome presents the highest frequency of open catalytic chamber conformation. Opposite results were observed in the C76 lineage. However, we noted an increased pool of oxidized proteins and protein aggregates in the C221 strain compared to the wild type. These data do not match with the increase of chronological life span observed in this lineage, but we believe that these aggregates are related to a kind of "sequestration" of potentially damaging proteins, as will be discussed in this work.

Keywords: Proteasome. Stress oxidative. Life span. S-glutathiolation. Aggregates. 


\section{ABREVIATURAS E SIGLAS}

19SPT

20SPT

26SPT

ATP

C221

$\mathrm{C} 221 \mathrm{~S}$

C76

C76S

ChT-L

Cys

Cys-SOH

Cys-SO2H

DNA

$\mathrm{DNPH}$

DTNB

DTT

GSH

GSSG

GR

Grx

$\mathrm{H}_{2} \mathrm{O}_{2}$

$\mathrm{kDa}$

MET

O.D

PA

PT-YPD

PT-SG

PT-SH

SAXS

T-L

Thr1
Proteassomo 19S - unidade regulatória

Proteassomo 20S - unidade catalítica

Proteassomo 26S - unidade regulatória acoplada à catalítica

Adenosina trifosfato

Linhagem de $S$. cerevisiae com proteassomo com a mutação $\alpha 5-\mathrm{C} 221 \mathrm{~S}$

Proteassomo com a mutação $\alpha 5-\mathrm{C} 221 \mathrm{~S}$

Linhagem de S. cerevisiae com proteassomo com a mutação $\alpha 5$-C76S

Proteassomo com a mutação $\alpha 5-\mathrm{C} 76 \mathrm{~S}$

Atividade tipo-quimiotripsina do proteassomo

Resíduo de cisteína

Resíduo de cisteína oxidado a ácido sulfênico

Cisteína oxidada a ácido sulfínico

Ácido desoxirribonucleico

2,4- Dinitrofenilhidrazina

5,5'-ditio-bis-(2-nitrobenzóico) ou reagente de Ellman

1,4-Ditiotreitol

Glutationa

Glutationa oxidada

Glutationa redutase

Glutarredoxina

Peróxido de hidrogênio

Kilo dáltons

Microscopia eletrônica de transmissão

Densidade ótica

Atividade pós-acídica do proteassomo

Proteassomo nativamente glutatiolado extraído de YPD

Proteassomo glutatiolado in vitro

Proteassomo reduzido com DTT

Small Angle X Ray Scattering

Atividade tipo-tripsina do proteassomo

Treonina 1 
$\operatorname{Trr}$

$\operatorname{Trx}$

$\mathrm{Ub}$

UPS

YPD
Tiorredoxina redutase

Tiorredoxina

Ubiquitina

Sistema Ubiquitina-Proteassomo

Peptona dextrose para levedura 


\section{LISTA DE ILUSTRAÇÕES}

Figura 1 - Curva de crescimento.

Figura 2 - Análise da tolerância ao estresse oxidativo das linhagens de levedura selvagem (WT) e mutante (C221 e C76).

Figura 3 - Ensaio do tempo de vida cronológico .38

Figura 4 - Ensaio do tempo de vida replicativo

Figura 5 - Imunomarcação com anticorpos anti-20SPT, anti-19SPT e anti-actina. .41

Figura 6 - Expressão gênica de subunidades proteassomais .42

Figura 7 - Avaliação da frequência de formas abertas do 20SPT por microscopia eletrônica de transmissão.

Figura 8 - Ensaio de atividade tipo-quimiotripisina do 20SPT e 26SPT no extrato celular total

Figura 9 - Capacidade proteolítica do 20SPT selvagem e mutante C221S. .46

Figura 10 - Conteúdo de enzimas anti-oxidantes nas linhagens . .48

Figura 11 - Conteúdo de proteínas glutatioladas nas linhagens. .50

Figura 12 - Conteúdo de proteínas oxidadas nas linhagens. .51

Figura 13 - Conteúdo intracelular de agregados proteicos nas linhagens. .52

Figura 14 - Identificação de proteínas agregadas. .53

Figura 15 - Conteúdo de proteínas poli-ubiquitinadas nas linhagens. .55

Figura 16 - Eletroforese bidimensional do extrato celular. .57

Figura 17 - Análise da resistência a rapamicina das linhagens .59 


\section{LISTA DE TABELAS}

Tabela 1 - Sequência dos primers utilizados nos ensaios de qPCR para análise da expressão de unidades do proteassomo (19S e 20S) e da chaperona Ump1 ('assembly' do

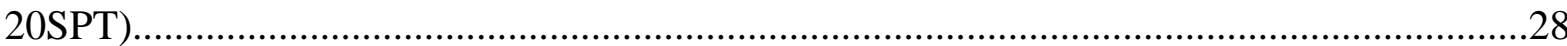

Tabela 2 - Atividade sítio-específica de preparações purificadas do 20SPT das linhagens

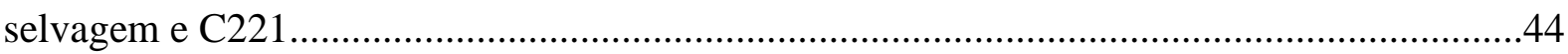

Tabela 3 - Razão GSH/GSSG e capacidade de remover $\mathrm{H}_{2} \mathrm{O}_{2}$ das linhagens selvagem e mutantes.

Tabela 4 - Proteínas identificadas nos agregados proteicos das linhagens de Saccharomyces cerevisiae selvagem e na mutante $\mathrm{C} 221$

Tabela 5 - Expressão proteica diferencial no extrato celular das linhagens de Saccharomyces cerevisiae selvagem e na mutante $\mathrm{C} 221$ 


\section{SUMÁRIO}

1 INTRODUÇÃO 17

1.1 Proteassomo 17

1.2 Degradação de proteínas oxidadas 19

$\begin{array}{ll}1.3 \text { Glutatiolação proteica } & 19\end{array}$

1.4 Glutatiolação do proteassomo 20

1.5 Linhagens mutantes C221 e C76 22

2 OBJETIVOS 23

3 MATERIAIS E MÉTODOS 23

\begin{tabular}{ll} 
3.1 Linhagens & 23 \\
\hline
\end{tabular}

3.1.1 Linhagens com mutação sítio-específica 23

3.2 Crescimento celular e preparação do extrato celular total 24

$\begin{array}{ll}3.3 \text { Curva de crescimento } & 24\end{array}$

3.4 Avaliação da tolerância ao estresse oxidativo 24

3.5 Ensaio do tempo de vida cronológico 25

3.6 Ensaio do tempo de vida replicativo 25

3.7 Ensaio de imunomarcação 26

3.8 Extração de RNA de levedura $S$. cerevisiae reação de transcrição reversa 26

3.9 Reação de qPCR 27

3.10 Purificação do proteassomo 20S 28

3.11 Análise do proteassomo 20S por microscopia eletrônica de transmissão 28

3.12 Ensaio de atividade sítio-específica $\quad 29$

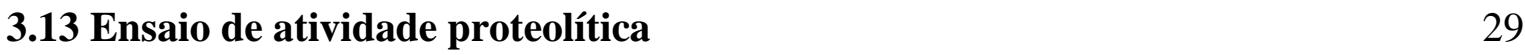

3.14 Conteúdo intracelular de glutationa total e oxidada 30

3.15 Avaliação da atividade da glutationa redutase 30

3.16 Capacidade de remover $\mathrm{H}_{2} \mathrm{O}_{2} \quad 31$

3.17 Avaliação do conteúdo intracelular de proteínas oxidadas 31

3.18 Isolamento de agregados proteicos 31

3.19 Análise proteômica $\quad 32$

3.19.1 Eletroforese bidimenmsional $\quad 32$

3.19.1.1 Preparo das amostras $\quad 32$

3.19.1.2 Primeira dimensão - Separação das proteínas pelo ponto isoelétrico (pI) 33

3.19.1.3 Segunda dimensão - Separação de proteínas pelo peso molecular 33

3.19.2 Identificação de proteína por espectrometria de massa 33

4 RESULTADOS 36

4.1 Alterações fenotípicas causada pela mutação sitio-específica 36

4.2 Não há alteração na expressão e na concentração de proteassomo entre as linhagens selvagem e mutantes $\quad 40$

4.3 Alterações estruturais e atividade catalítica do proteassomo 42 
4.4 Avaliação dos parâmetros redox

4.5 Análise proteômica

5 DISCUSSÃO

6 CONCLUSÕES 


\section{INTRODUÇÃO}

Para manter a funcionalidade e a viabilidade celular, é importante que as proteínas possuam um dobramento definido. Sendo assim, proteínas danificadas ou com erros de tradução devem ser reconhecidas e degradadas (FINLEY, 2009; HERSHKO et al., 2000; HOFFMAN; RECHSTEINER, 1996; PICKART; COHEN, 2004; VOGES et al., 1999;). Dentre os processos proteolíticos intracelulares, o sistema ubiquitina-proteassomo (UPS) é a principal via não-lisossomal para a degradação de proteínas intracelulares danificadas e desempenha um papel importante na regulação de diversos processos celulares, representando assim, a mais importante via na manutenção da homeostase celular.

\subsection{Proteassomo}

O proteassomo é um complexo proteico responsável pelo reconhecimento e degradação de diversas proteínas celulares envolvidas em várias funções essenciais para a viabilidade celular, como a regulação do ciclo, sinalização celular, geração de peptídeos imunogênicos e a eliminação de proteínas danificadas durante síntese proteica (BERLETT; STADTMAN, 1997; BOCHTLER et al., 1999; COUX et al., 1996; GIULIVI et al., 1994; ULLRICH et al., 1999).

O proteassomo é encontrado no citoplasma e no núcleo de células eucarióticas. Entretanto, sua abundância nestes compartimentos é muito variável, pois no citoplasma estão associados aos centrossomos e retículo endoplasmático, e no núcleo, está presente em todo o nucleoplasma, mas ausentes no nucléolo (PALMER et al., 1996; RIVETT et al., 1992; WIGLEY et al., 1999). Possui uma unidade catalítica central denominada de proteassomo $20 \mathrm{~S}$ (20SPT), e uma ou duas unidades regulatórias (19SPT) que estão ligadas em uma ou ambas as extremidades da porção central para formar o proteassomo denominado de $26 \mathrm{~S}$ (26SPT).

A unidade catalítica $20 \mathrm{~S}$ tem peso molecular de aproximadamente $750 \mathrm{kDa}$, e as subunidades estão organizadas em quatro anéis heptaméricos superpostos em forma de barril 
(11-12 $\mathrm{nm}$ de largura por 15-16 nm de comprimento e um estreito poro de 2-3 nm de diâmetro). Os dois anéis idênticos externos são constituídos por sete subunidades distintas denominadas do tipo $\alpha(\alpha 1-\alpha 7)$, responsáveis pela abertura e fechamento da câmara catalítica. Os outros dois anéis internos são formados por sete subunidades distintas do tipo $\beta$ ( $\beta 1$ - $\beta 7)$, onde se situam os sítios catalíticos (JUNG et al., 2009; TANAKA, 1995; 1998).

As subunidades catalíticas ativas $(\beta 1, \beta 2$ e $\beta 5)$ possuem o resíduo de treonina 1 (Thr1) como sítio-ativo, onde ocorre a hidrólise da ligação peptídica dos substratos pela ação da hidroxila da cadeia lateral da Thr1 que age como nucleófilo (GROLL et al., 1999). O 20SPT é uma protease multicatalítica: a subunidade $\beta 1$ possui atividade pós-acídica (PA), clivando após resíduos ácidos; a subunidade $\beta 2$ possui atividade tipo-tripsina (T-L), clivando após resíduos básicos, e, a subunidade $\beta 5$ possui atividade do tipo-quimiotripsina (ChT-L), hidrolisando cadeias peptídicas após aminoácidos hidrofóbicos (ARENDT; HOCHSTRASSER, 1997; DICK et al., 1998; HEINEMEYER et al., 1997; NUSSBAUM et al., 1998; RIVETT, 1989).

Juntamente à unidade catalítica central 20S, complexos proteicos regulatórios podem se associar por interação com as subunidades $\alpha$, modulando a atividade do proteassomo. Um importante complexo regulatório denominado $19 \mathrm{~S}$ é responsável pelo reconhecimento de substratos poli-ubiquitinados, desubiquitinação do substrato, desdobramento das proteínasalvo e a translocação do substrato para o interior da câmara catalítica 20S (GLICKMAN et al., 1998; NAVON; GOLDBERG, 2001).

O sistema ubiquitina-proteassomo é dependente de ATP, tanto para a etapa de marcação da proteína alvo com ubiquitina quanto na etapa de desdobramento e translocação do substrato para a câmara catalítica. A ubiquitina (Ub) é uma pequena proteína de 8,5 kDa, com 76 aminoácidos, altamente conservada evolutivamente, considerada ubíqua nos diversos reinos (SCHLESINGER et al., 1975; WILKINSON et al., 1980). 


\subsection{Degradação de proteínas oxidadas}

A unidade catalítica do proteassomo (20SPT) também é capaz de degradar proteínas oxidadas por um mecanismo independente de ATP e ubiquitina. A remoção de proteínas oxidadas pelo 20SPT é considerada uma defesa anti-oxidante e preventiva de agregação proteica (DAVIES, 2001; PICKERING; DAVIES, 2012; VARSHAVSKY, 2005).

O processo de oxidação de proteínas é um fenômeno intracelular permanente, intensificando-se durante condições de estresse oxidativo (DAVIES, 2000; FERRINGTON et al., 2001). A degradação seletiva de proteínas oxidadas pelo 20SPT tem sido intensamente investigada e tudo indica que essas proteínas não dependem de poli-ubiquitinação para serem reconhecidas e degradadas pelo 20SPT (BAUGH et al., 2009; INAI; NISHIKIMI, 2002; JUNG et al., 2007; SHRINGARPURE et al., 2003). O mecanismo pelo qual as proteínas oxidadas interagem com o 20SPT ainda não é muito bem caracterizado. O aumento de hidrofobicidade superficial dessas proteínas parece ser uma característica importante para permitir a interação proteína-20SPT e consequente degradação (PACIFICI et al., 1993).

O acúmulo de proteínas oxidadas tanto devido ao aumento do processo oxidativo quanto ao decréscimo de sua remoção, está fortemente associado ao processo de envelhecimento e doenças neurodegenerativas. Uma proteína oxidada perde a sua conformação natural expondo a sua parte hidrofóbica levando a formação de agregados proteicos intracelulares. Uma vez que o acúmulo desses agregados está diretamente relacionado a doenças neurodegenerativas, proteínas oxidadas devem ser rapidamente reconhecidas e degradadas pelo proteassomo (BUTTERFIELD et al., 2006; STADTMAN, 2006).

\subsection{Glutatiolação proteica}

Já foram descritas algumas modificações pós-traducionais sofridas pelo 20SPT em diversos organismos, tais como: acetilação, fosforilação, glicação e a S-glutatiolação. Apesar 
de identificadas, muitas ainda não possuem função fisiológica conhecida. Existem interpretações e alguns dados indiretos de que essas modificações estejam correlacionadas com a modulação da atividade proteolítica, manutenção da meia-vida da unidade $20 \mathrm{~S}$ e no processo de associação das subunidades para a montagem do 20SPT (CARRARD et al., 2003; DAHLMANN, 2007; GOMES et al., 2006; KIKUCHI et al., 2010; ZONG et al., 2008).

Entre as modificações pós-traducionais sofridas pelo 20SPT está a S-glutatiolação, que é à adição de glutationa nos resíduos de cisteína (DEMASI et al., 2001).

A S-glutatiolação é uma modificação química pós-traducional reversível que atua como um mecanismo de regulação redox da atividade de diversas proteínas e funções celulares associadas, assim como fornecendo proteção a cisteínas proteicas contra oxidação irreversível e servindo como transdutor de sinal redox (SHELTON; MIEYAL, 2008).

A glutationa é um tri-peptídeo ( $\gamma$-GluCysGly) encontrado em algumas eubactérias e em todos os organismos eucarióticos. Ocorre em suas formas reduzida (GSH) e oxidada (GSSG), atuando direta ou indiretamente em muitos processos para a manutenção da homeostase redox (SIES, 1999). São inúmeros os mecanismos de glutatiolação proteica, dentre eles a troca tiol-dissulfeto (P-SH / GSSG) ou reação de GSH com o derivado oxidado do tiol proteico, ácido sulfênico (Cys-SOH).

\subsection{Glutatiolação do proteassomo}

A S-glutatiolação do 20SPT foi primeiramente observada em células de mamíferos (epitélio hepático de ratos) incubadas com inibidores irreversíveis e específicos do proteassomo, tais como lactacistina, NLVS e $\beta$-lactona. Também foi observado que preparações de 20SPT purificadas de eritrócito humano e de eritroblasto de coelho apresentaram atividade tipo-quimiotripsina, porém, não a tipo-tripsina, modulada pela incubação com GSH, GSSG e cisteína. Assim, com base nessas observações, ficou 
demonstrado que a modulação da atividade do proteassomo por GSH e GSSG in vitro, era um fenômeno consequente da S-glutatiolação do 20SPT (DEMASI et al., 2001).

Em 2003, Demasi et al., descreveram o mecanismo in vitro pelo qual ocorre o processo de S-glutatiolação do 20SPT de levedura Saccharomyces cerevisiae. Os resultados deste trabalho demonstraram que durante o estresse oxidativo, resíduos de cisteínas do 20SPT podem ser oxidados para Cys-SOH seguido de S-glutatiolação pela forma reduzida da glutationa.

A vantagem metabólica da glutatiolação proteica na sinalização redox é a prevenção contra a oxidação irreversível do grupo tiol da cisteína à Cys- $\mathrm{SO}_{2} \mathrm{H}$ ou Cys- $\mathrm{SO}_{3} \mathrm{H}$, permitindo a reativação da proteína por redução (DEMASI et al., 2003).

Dados obtidos por SILVA et al., (2008), mostraram a desglutatiolação do 20SPT por oxidoredutases (glutarredoxina 1 e tiorredoxinas 1 e 2 ) demonstrando a possível reversibilidade intracelular do processo.

A identificação dos resíduos de cisteína glutatiolados do proteassomo foi primeiramente realizada através da separação das subunidades do 20SPT por gel 2-DE, seguido de espectrometria de massas (SILVA et al., 2012).

A análise do 20SPT quando glutatiolado in vitro permitiu a identificação de três diferentes subunidades glutatioladas $(\alpha 5, \alpha 6$ e $\alpha 7)$ e um total de seis resíduos de cisteína distribuídos entre elas. Já no 20SPT isolado de leveduras crescidas em YPD (4\% de glicose) até fase estacionária, foram encontradas duas Cys glutatioladas em uma única subunidade (Cys76 e Cys221 na subunidade $\alpha 5$ ), sugerindo assim uma especificidade in vivo no processo de regulação redox do 20SPT.

Em relação aos resíduos de Cys encontrados glutatiolados, apenas a Cys221 contida na subunidade $\alpha 5$ apresenta a sulfidrila totalmente exposta ao solvente, no entanto a Cys76 é 
altamente conservada ao longo da escala evolutiva, estando presente desde a levedura até ao homem.

Os resíduos de cisteína identificados por Silva et al., (2012) como glutatiolados concentram-se exclusivamente nas subunidades $\alpha$ do proteassomo 20S. Uma das consequências estruturais dessa modificação em subunidades $\alpha$, além das alterações funcionais sítio-específicas estudadas anteriormente, foi a observação de que quando esses resíduos encontram-se glutatiolados ocorre a abertura da câmara catalítica da partícula 20S, observado por microscopia eletrônica de transmissão (MET) e SAXS (Small Angle X-ray Scattering), e consequentemente um aumento de degradação de proteínas oxidadas.

\subsection{Linhagens mutantes C221 e C76}

Recentemente, foram obtidas duas linhagens da levedura S. cerevisiae (C221 e C76) com mutações sítio-específicas pela substituição dos resíduos de Cys glutatioláveis em meio YPD, por serina. Ensaios comparativos com essas linhagens mutante e selvagem mostraram que a linhagem C221 possui crescimento e uma resistência ao estresse oxidativo aumentados quando comparada com a linhagem selvagem, enquanto que a linhagem C76 possui uma dificuldade no crescimento. O estudo da glutatiolação do proteassomo mostrou-se interessante devido a sua conservação em diversos organismos e também pelo fato de ser uma modificação com importante papel funcional.

O entendimento deste mecanismo de regulação e a importância de cada Cys no processo de modulação da atividade catalítica contribuirão para a caracterização do processo. Estas Cys poderiam se tornar alvos de inibidores ou ativadores específicos para o proteassomo, importante alvo para tratamentos de doenças neurodegenerativas (MATSUDA; TANAKA, 2010; MONTAGUT et al., 2006; PETRUCELLI; DAWSON, 2004). 


\section{OBJETIVOS}

O objetivo geral deste projeto consistiu em avaliar o papel de resíduos de Cys glutatioláveis na atividade do 20SPT.

Dentre os objetivos específicos, avaliar a tolerância ao estresse oxidativo, capacidade de remoção de proteínas oxidadas e a expectativa de vida das linhagens mutantes (C22S, C76) da levedura S. cerevisiae. Ainda, avaliar os parâmetros redox das linhagens selvagem e mutantes (C221 e C76) com o intuito de justificar as alterações fenotípicas causada pela mutação sítio-específica no 20SPT.

\section{MATERIAIS E MÉTODOS}

\subsection{Linhagens}

A linhagem selvagem de levedura utilizada na execução deste trabalho foi a RJD1144 (MATa his3_200 leu2-3,112, lys2-801 trp1_63 ura3-52 PRE1 FH ::Ylplac211 URA3) de Saccharomyces cerevisiae derivada da linhagem JD47-13C. Esta linhagem possui uma cauda de polihistidina e a sequência do peptídeo FLAG (Asp-Tyr-Lys-Asp-Asp-Asp-Asp-Lys) fusionadas à subunidade Pre1 $(\beta 4)$ do proteassomo. Essa linhagem foi gentilmente cedida pelo Dr. Raymond Deshaies da Divisão de Biologia, Caltech, Pasadena, CA-EUA.

\subsubsection{Linhagens com mutação sítio-específica}

As linhagens com mutações sítio-específicas estudadas neste trabalho foram realizadas pela Doutoranda do grupo, Janaina de Moraes Maciel Leme, com a colaboração do Dr. Mario Henrique Barros (Departamento de Microbiologia - ICB-USP). A técnica, de domínio do grupo do Dr. Mario, está descrita em: HERMAN; HICKS (1991); ROSE et al., (1990); ROTHSTEIN (1983); SCHIESTl et al., (1989). 


\subsection{Crescimento celular e preparação do extrato celular total}

O crescimento da levedura foi padronizado em meio rico YPD (1\% de extrato de levedura, $2 \%$ de peptona e $4 \%$ de glicose) durante 60 horas de incubação a $30{ }^{\circ} \mathrm{C}$ sob agitação constante de 200 rpm. Para a obtenção do pellet, após o crescimento celular, os meios foram submetidos a 3 ciclos de centrifugação durante 7 minutos, $8500 \mathrm{rpm}$ a $4{ }^{\circ} \mathrm{C}$, intercalados com a lavagem das células com $\mathrm{H}_{2} \mathrm{O}$ milliQ para remover o excesso de meio de cultura.

Para obter o extrato celular total, as células foram ressuspendidas em tampão Tris-HCl (20 mM Tris- $\mathrm{HCl} \mathrm{pH}$ 7,5, $5 \mathrm{mM}$ de $\mathrm{MgCl}_{2}$ e $20 \mathrm{mM} \mathrm{KCl}$ ) e rompidas por agitação vigorosa com pérolas de vidro a $4{ }^{\circ} \mathrm{C}$ durante 60 minutos e o extrato celular obtido foi centrifugado a $15000 \mathrm{rpm}$ por 45 minutos a $4{ }^{\circ} \mathrm{C}$.

\subsection{Curva de crescimento}

Os inóculos foram obtidos a partir de células cultivadas em meio YPD 4\% durante 12 horas. As células foram diluídas até uma densidade óptica (O.D) de 0,1 ( $\lambda 600 \mathrm{~nm})$ e inoculadas em $50 \mathrm{ml}$ de meio YPD contendo $4 \%$ de glicose e incubadas a $30{ }^{\circ} \mathrm{C}$ sob agitação contínua de 200 rpm durante 60 horas. As medições da absorbância foram feitas de duas em duas horas. Construiu-se um gráfico com os dados para a visualização da curva de crescimento.

\subsection{Avaliação da tolerância ao estresse oxidativo}

Para analisar a sensibilidade das linhagens selvagem e mutantes C221 e C76 a diferentes tratamentos com peróxido de hidrogênio utilizamos o método adaptado a partir de Munhoz e Netto (2004). Os inóculos foram obtidos a partir de células cultivadas em meio YPD $4 \%$ durante 12 horas e a $30^{\circ} \mathrm{C}$. Após 60 horas de crescimento, as culturas de células foram diluídas até uma O.D de $0,8(\lambda 600 \mathrm{~nm})$ e submetidas a diluição seriada $(1 / 5,1 / 25$, 
1/125, 1/325). Uma gota de $5 \mu \mathrm{l}$ de cada diluição foi plaqueada em YPD (1\% de extrato de levedura, $2 \%$ de peptona, $2 \%$ de ágar e $4 \%$ de glicose) contendo diferentes concentrações de $\mathrm{H}_{2} \mathrm{O}_{2}(0,5-2 \mathrm{mM})$. Finalmente, as placas foram avaliadas após 48 horas de incubação em estufa a $30^{\circ} \mathrm{C}$.

\subsection{Ensaio do tempo de vida cronológico}

Primeiramente, os inóculos foram obtidos a partir de células cultivadas em meio YPD 4\% durante 12 horas. As linhagens de levedura (mutantes e selvagem) foram inoculadas a O.D 0,2 e crescidas sob agitação constante de $200 \mathrm{rpm}$ a $30{ }^{\circ} \mathrm{C}$ em meio mínimo sintético completo ( $2 \%$ de glicose, $0,17 \%$ de YNB, $0,5 \%$ de sulfato de amônio e $0,12 \%$ de uma mistura de aminoácidos essenciais com exceção de Try, Leu e His). O tempo de vida cronológico é determinado pela habilidade de formação de colônias em um meio de cultura. Para isso, a cada 48 horas de crescimento, 100 células da cultura foram semeadas em placas de YPD sólido (ágar 2\%), e após 48 horas de incubação na estufa a $30^{\circ} \mathrm{C}$, as colônias foram contadas (OLIVEIRA et al., 2008; TAHARA et al., 2007).

\subsection{Ensaio do tempo de vida replicativo}

Esse ensaio foi realizado em colaboração com o Dr. Mário Henrique de Barros do Departamento de Microbiologia (ICB-USP). O protocolo utilizado está descrito detalhadamente em Steffen et al., (2009). Sucintamente: As células de levedura inicialmente crescidas em placas YPD ( $2 \%$ de glicose) à $30^{\circ} \mathrm{C}$, foram transferidas e espalhadas sobre uma nova placa YPD (2\% de glicose) para o isolamento de colônias. Foram selecionadas 40 células-filhas, também denominadas de virgens, de cada uma das linhagens examinadas (WT, C221 e C76) através de um micromanipulador. A cada geração observada (2 horas), as células 
filhas foram contadas e descartadas. Esse procedimento se repetiu até o momento que cessou a replicação

\subsection{Ensaio de imunomarcação}

Para analisar as concentrações de algumas enzimas anti-oxidantes e verificar as concentrações do proteassomo 20S e 19S nas linhagens WT, C221 e C76, foi feito o ensaio de imunomarcação com anticorpos anti-actina (ICM), anti-20SPT (Calbiochem), anti-19SPT (Calbiochem), anti-Trr1, anti-Trr2, anti-Grx2, anti-mPrx1, anti-Tsa1 (anticorpos produzidos pelo nosso laboratório através da imunização de coelho com proteínas recombinantes purificadas pelo nosso grupo). Foram aplicados $30 \mu \mathrm{g}$ de extrato celular total em gel SDSPAGE 12,5-15\%. Após transferência das amostras para membrana de nitrocelulose foi feita a marcação com os anticorpos. A revelação foi feita por quimioluminescência e a emissão registrada por fotodocumentador. Como controle de loading, as membranas foram coradas com Ponceau red (0,1\% Ponceau Red, $5 \%$ de ácido acético).

\subsection{Extração de RNA de levedura $S$. cerevisiae reação de transcrição reversa}

As células foram cultivadas em $10 \mathrm{ml}$ de YPD 4\% até atingirem à fase exponencial $(\mathrm{OD}=1,0)$, e coletadas por centrifugação, com os devidos ajustes de volume para obtenção da mesma quantidade de células de todas as amostras. A extração do RNA das células se deu pelo método do fenol ácido quente (AUSUBEL et al., 1994). As células foram rompidas com TES (Tris-HCl $10 \mathrm{mM}$, EDTA $10 \mathrm{mM}$, SDS 0,5\%) na presença de fenol ácido e clorofórmio e, em seguida, o RNA total foi precipitado com etanol absoluto e acetato de $\mathrm{M}$ ( $\mathrm{pH} 5,3$ ), lavado com etanol $70 \%$ e ressuspendido em $50 \mu$ l de água milliQ. A concentração de RNA total determinada em espectrofotômetro de alta sensibilidade (Gen5 Data Analysis Software, BioTek, Winooski, Vermont, United States of America). A qualidade do RNA extraído foi 
avaliada através da análise da razão entre as absorbâncias em $\lambda=260 \mathrm{~nm}$ e $\lambda=280 \mathrm{~nm}$ e da análise da integridade das subunidades de RNA ribossomal (18S e 28S) sob luz UV, após separação por eletroforese em gel de agarose (1\%) contendo brometo de etídio.

A reação de transcrição reversa, para síntese da fita complementar ao mRNA (cDNA), foi realizada utilizando-se $1 \mu \mathrm{g}$ do RNA total segundo as especificações fornecidas pelo fabricante da enzima transcriptase reversa (M-MLV Reverse Transcriptase, Invitrogen/Life Technologies, Carlsbad, California, United States of America) em termociclador (PTC 200 Termocycler, MJ Research, Walthan, Massachusetts, United States of America).

\subsection{Reação de qPCR}

As reações de qPCR foram realizadas segundo protocolo do fabricante do reagente Platinum SYBR Green qPCR UPSer Mix-UDG (Invitrogen/Life Technologies, Carlsbad, California, United States of America). Curvas de concentração de primer e cDNA foram previamente realizadas para a padronização das condições do ensaio. As amostras foram avaliadas em duplicata, em três experimentos independentes, sempre na presença de um controle negativo (ausência de cDNA). No termociclador, as amostras foram submetidas a 40 ciclos de temperatura $\left(95^{\circ} \mathrm{C}\right.$ por $2 \mathrm{~min} ; 95^{\circ} \mathrm{C}$ por 15 segundos; $60{ }^{\circ} \mathrm{C}$ por 1 min; $72{ }^{\circ} \mathrm{C}$ por 15 segundos). Os níveis de cDNA foram determinados através do cálculo 2- $\Delta \Delta \mathrm{Ct}$, sendo $\Delta \Delta \mathrm{Ct}=(\Delta \mathrm{Ct}$ Tratado $-\Delta \mathrm{Ct}$ Controle $)$ e $\Delta \mathrm{Ct}=(\mathrm{Ct}$ gene interesse $-\mathrm{Ct}$ controle interno $) . \mathrm{O}$ valor do Ct representa a linha de base para detecção da fluorescência emitida, correspondente à fase exponencial, conforme a amplificação do material genético analisado. Os níveis de GAPDH foram utilizados como controle interno. As sequências dos primers utilizados encontram-se descritas na tabela a seguir: 
Tabela 1 - Sequência dos primers utilizados nos ensaios de qPCR para análise da expressão de unidades do proteassomo (19S e 20S) e da chaperona Ump1 ('assembly' do 20SPT).

\begin{tabular}{ccc}
\hline Genes & Sequência sense & Sequência anti-sense \\
\hline PUP2 & 5'- TAACGCAATCGGTGTGTGAT -3' & 5'- ATGGCCAGCAATTAACAAGG -3' \\
UMP1 & 5'-GACACATTACGCCAGCAAGA -3' & 5'- CTTTTCATTGGTTCGGCAAT -3' \\
PRE6 & 5'-GACCATTGGGAGAAACTCCA -3' & 5'- TGTTCGATTTGGGTGACGTA -3' \\
PRE1 & 5'- TCATGGTTACTCGGGGTTTT -3' & 5'-AACAATGACGCCCTTGAAGT -3' \\
PRE9 & 5'-CGCCGGTTATGACGATAGAT -3' & 5'- TAGGGTTTGTGCTGCTGATG -3' \\
RPT1 & 5'-AAGTTGTCGAGCTGCCCTTA -3' & 5'- GCTCAGACCCAATGACCCTA -3'
\end{tabular}

Os dados foram expressos como média \pm desvio-padrão e representados como vezes de indução/variação em relação ao controle. Os primers foram desenhados e sintetizados de acordo com os programas PrimerQuestSM e OligoAnalyser 3.1 (Integrated DNA Technologies-IDT, Coralville, Iowa, United States of America).

\subsection{Purificação do proteassomo 20S}

O proteassomo contido no extrato proteico foi purificado em colunas de afinidade a níquel HisTraptm FF (GE Healthcare) de acordo com o manual do fabricante. A eluição do proteassomo foi realizada em gradiente linear de imidazol no sistema ÄKTA purifier (GE Healthcare). Após a determinação da atividade proteolítica, as alíquotas ativas foram concentradas em filtros Amicon Ultra YM-100 e dessalinizadas em colunas PD-10 Desalting (GE Healthcare) para Tampão Padrão (20 mM Tris- $\mathrm{HCl} \mathrm{pH} 7,5,5 \mathrm{mM}$ de $\mathrm{MgCl}_{2}$ e $20 \mathrm{mM}$ $\mathrm{KCl}$ ) (DEMASI et al., 2003).

\subsection{Análise do proteassomo $20 S$ por microscopia eletrônica de transmissão}

A técnica de MET está padronizada pelo grupo, sendo realizado no Laboratório de Biologia Celular do Instituto Butantan, em colaboração com o Prof. Dr. Cristiano L. P. de Oliveira e sua aluna de mestrado, Renata N. Bicev, ambos do Departamento de Física Experimental, Instituto de Física, USP. As análises são realizadas em Microscópio Eletrônico de Transmissão LEO 906E (Zeiss, Alemanha) com voltagem de aceleração de $100 \mathrm{kV}$. As imagens são capturadas por câmera integrada Megaview III utilizando o software iTEM Universal TEM Imaging Platform (Olympus Soft Imaging Solutions GMBh, Alemanha). 
Resumidamente, as amostras de 20SPT previamente purificadas foram adicionadas em microtelas cobertas com um fino filme de parlódio (polímero de celulose) recobertas com carvão. As amostras foram coradas negativamente utilizando solução de ácido fosfotungstico a $2 \%$ como corante.

\subsection{Ensaio de atividade sítio-específica}

A atividade catalítica do proteassomo $20 \mathrm{~S}$ purificado e do proteassomo $20 \mathrm{~S}$ e $26 \mathrm{~S}$ no extrato celular da linhagem selvagem e das mutantes C221 e C76 foram avaliadas para a atividade tipo-quimiotripsina (ChT-L), tipo-tripsina (T-L) e pós-acídica (PA), utilizando-se peptídeos fluorogênicos (suc-LLVY-MCA, z-ARR-AMC e z-LLE-AMC, respectivamente) como substratos. Alíquotas de preparação de proteassomo foram incubadas com $50 \mu \mathrm{M}$ de substrato peptídico em tampão $20 \mathrm{mM}$ Tris- $\mathrm{HCl} \mathrm{pH}$ 7,5 por 45 minutos a $37{ }^{\circ} \mathrm{C}$. Para avaliar a atividade no extrato celular, foram incubadas $60 \mu \mathrm{g}$ do extrato celular com $50 \mu \mathrm{M}$ de substrato peptídico em tampão $20 \mathrm{mM}$ Tris- $\mathrm{HCl} \mathrm{pH} 7,5$ por 45 minutos a $37{ }^{\circ} \mathrm{C}$. Para medir a atividade do $26 \mathrm{~S}$ foi utilizado o mesmo protocolo, mas também com a presença de $5 \mathrm{mM}$ de ATP. A emissão da fluorescência é capturada a $440 \mathrm{~nm}$ (excitação a $365 \mathrm{~nm}$ ) em espectrofluorímetro.

\subsection{Ensaio de atividade proteolítica}

Para este ensaio foram utilizadas proteínas-padrão, ou seja, proteínas que sabidamente são degradadas in vitro pelo 20SPT por processo independente de poli-ubiquitinação. Nos experimentos mostrados neste trabalho utilizamos (1) glutarredoxina2 (Grx2), oxidoredutase que, como observado pelo nosso grupo (SILVA et al., 2008, 2012), é degradada pelo 20SPT; (2) caseína e (3) $\alpha$-sinucleína. As condições dos ensaios estão descritas na legenda das figuras. 
Para que a degradação destas proteínas e o surgimento de fragmentos peptídicos pudessem ser acompanhados, as amostras foram aplicadas em gel SDS-PAGE.

\subsection{Conteúdo intracelular de glutationa total e oxidada}

Células coletadas após o crescimento específico foram lisadas por agitação vigorosa com esferas de vidro em 3,5\% de ácido sulfosalicílico para precipitação proteica. Os homogenatos foram centrifugados a $15000 \mathrm{rpm}$ por 15 minutos a $4{ }^{\circ} \mathrm{C}$ e o sobrenadante foi então separado para as dosagens. $\mathrm{O}$ ensaio de glutationa total foi realizado em tampão $0,1 \mathrm{M}$ fosfato de potássio pH 7,0 contendo $1 \mathrm{mM}$ EDTA, seguido da adição de 0,2 mM NADPH, 80 nM de DTNB e $120 \mathrm{mU}$ de glutationa redutase. A absorbância foi acompanhada a $412 \mathrm{~nm}$ por 2 minutos a $37{ }^{\circ} \mathrm{C}$. Para a dosagem de glutationa oxidada (GSSG), alíquotas da amostra inicial foram separadas e tiveram suas as sulfidrilas livres de GSH alquiladas na presença de 5 mM de NEM. O pH foi ajustado para 7,0 e as alíquotas foram então, incubadas durante uma hora à temperatura ambiente. Alíquotas de $50 \mu \mathrm{l}$ foram retiradas para o mesmo ensaio. Glutationa reduzida (GSH) foi determinada pela diferença entre glutationa total e a glutationa oxidada. A quantificação das amostras foi realizada de acordo com uma curva padrão de GSSG e padronizada pela massa celular total.

\subsection{Avaliação da atividade da Glutationa Redutase}

Células coletadas após o crescimento padrão foram lisadas por agitação vigorosa com pérolas de vidro em Tampão Fosfato de potássio 0,1 M pH 7,0. O homogenato foi centrifugado a $15000 \mathrm{rpm}$ por 15 minutos a $4{ }^{\circ} \mathrm{C}$ e o sobrenadante foi então separado para as dosagens. A atividade da GR foi medida pela reação 1: Tampão $0,1 \mathrm{M}$ fosfato de potássio $\mathrm{pH}$ 7,0 contendo $5 \mathrm{mM}$ NADPH, $4 \mathrm{mM}$ de DTNB e $50 \mu \mathrm{l}$ de extrato celular total; e pela reação 2: Tampão 0,1 M fosfato de potássio pH 7,0 contendo $5 \mathrm{mM}$ NADPH, $4 \mathrm{mM}$ de DTNB, $1 \mathrm{mM}$ 
de GSSG e $50 \mu 1$ de extrato celular total. A absorbância foi acompanhada a $412 \mathrm{~nm}$ por 2 minutos a $37{ }^{\circ} \mathrm{C}$. Dessa forma, a atividade da GR é o resultado da subtração de reação 2 menos a reação 1 .

\subsection{Capacidade de remover $\mathrm{H}_{2} \mathrm{O}_{2}$}

Para determinar a capacidade de remoção de $\mathrm{H}_{2} \mathrm{O}_{2}, 10$ - $1000 \mu \mathrm{g}$ de extrato protéico total fresco foram incubados em $0,1 \mathrm{M}$ de tampão fosfato $\mathrm{pH} 7,0$ por 2 min a $37{ }^{\circ} \mathrm{C}$ na presença de $2 \mathrm{mM} \mathrm{H}_{2} \mathrm{O}_{2}$. Uma alíquota de 2,5 $\mu 1$ foi retirada e diluída em $200 \mu 1$ do tampão de suspensão contendo $50 \mu \mathrm{M}$ Amplex Red e 1,0 U/ml de Horseradish Peroxidase (HRP). Fluorescência foi determinada a 587 nm (excitação a $563 \mathrm{~nm}$ ).

\subsection{Avaliação do conteúdo intracelular de proteínas oxidadas}

O conteúdo intracelular de proteínas oxidadas foi determinado através de imunomarcação originariamente descrito por Shacter et al., (1994) e amplamente utilizado pelo grupo (da CUNHA et al., 2011). Foram incubados $75 \mu \mathrm{g}$ de extrato celular total com 40 $\mu \mathrm{l}$ de DNPH 20 mM e $29 \mu$ de SDS $24 \%$ por 30 minutos protegido da luz. Após o tempo de incubação, $60 \mu \mathrm{l}$ de Sol B (Tris-HCl 2 M, 30\% de glicerol, 19\% de b-mercaptoetanol) foi adicionada a mistura. Alíquotas $30 \mu 1$ mais 7,5 $\mu 1$ de tampão de amostra foi aplicada em gel de poliacrilamida $8,5 \%$, seguido de transferência em membrana de nitrocelulose. A membrana foi corada com Ponceau red para o controle de loading e por fim, marcada com anti-DNP.

\subsection{Isolamento de agregados proteicos}

Para analisar o conteúdo de agregados proteicos intracelular das linhagens selvagem e mutantes C221 e C76 utilizamos o protocolo adaptado a partir de Koplin el al (2010). Para obter as células lisadas, o pellet foi ressuspendido em tampão de lise (20 mM Na-fosfato - pH 
6.8, $10 \mathrm{mM}$ DTT, $1 \mathrm{mM}$ EDTA, 0.1\% Tween, coquetel inibidor de protease [Sigma], $1 \mu 1$ Lactacistina $10 \mathrm{mM}$ [Calbiochem] $3 \mathrm{mg} / \mathrm{ml}$ zimoliase T20 e $1.25 \mathrm{U} / \mathrm{ml}$ benzonase) e incubados por 90 minutos a $30{ }^{\circ} \mathrm{C}$ sob agitação. As amostras foram sonicadas (10 ciclos, 10 segundos de sonicamento, 50 segundos de descanço e amplitude de 50\%) e centrifugadas por 20 minutos, 200 g a $4{ }^{\circ} \mathrm{C}$. O sobrenadante foi coletado e a concentração de proteínas ajustadas, e centrifugada novamente por 20 minutos, 16000 g a $4{ }^{\circ} \mathrm{C}$. Após a remoção do sobrenadante, o pellet de agregados foi lavado uma vez com tampão (20 mM Na-fosfato - pH 6,8 e $2 \%$ NP-40) e centrifugado por 20 minutos, $16000 \mathrm{~g} \mathrm{a} 4{ }^{\circ} \mathrm{C}$. Removeu-se o sobrenadante e o pellet de agregados ressuspendidos com $30 \mu \mathrm{l}$ de tampão Na-fosfato $20 \mathrm{mM}$. Essa amostra foi sonicada por 20 minutos antes e depois da adição do tampão de amostra 5 x e aplicadas ao gel SDS-PAGE $15 \%$.

\subsection{Análise proteômica}

\subsubsection{Eletroforese bidimenmsional}

Para análise proteômica, foi realizado o gel 2-DE do extrato celular total das linhagens selvagem e mutante C221.

\subsubsection{Preparo das amostras}

O pellet celular foi ressuspendido em tampão de re-hidratação (Uréia 8 M, CHAPS 2\% $\mathrm{m} / \mathrm{v}$, Pharmalytes 3-10 0,5\% v/v, DTT $13 \mathrm{mM}$, azul de bromofenol 0,007\% m/v) e as células rompidas por agitação vigorosa com pérolas de vidro a $4{ }^{\circ} \mathrm{C}$ durante 60 minutos, o extrato celular obtido foi centrifugado a $15000 \mathrm{rpm}$ por 45 minutos a $4{ }^{\circ} \mathrm{C}$. Um volume de amostra, equivalente a $200 \mu \mathrm{g}$ de proteína foi aplicado no cassete de re-hidratação (GE Healthcare). Em seguida, as tiras de gradiente de $\mathrm{pH} 4-7$ de $7 \mathrm{~cm}$ foram posicionadas de uma forma que o 
lado do gel ficasse voltada para a amostra. As tiras ficaram incubadas a temperatura ambiente por 16 horas.

\subsubsection{Primeira dimensão - Separação das proteínas pelo ponto isoelétrico (pI)}

As tiras foram retiradas do cassete de re-hidratação e transferidas para a cuba de corrida (IPGphor3 - GE Healthcare), montada de acordo com o manual do fabricante. Após a montagem dos eletrodos, as tiras foram cobertas com óleo mineral sendo, então, efetuada a corrida (4 horas a $100 \mathrm{~V}, 2$ horas a $250 \mathrm{~V}, 5$ horas em gradiente até $4000 \mathrm{~V}$ e por fim acúmulo de 80.000 Volt-h em constante de 4000 V). Após a corrida, procedeu-se a segunda dimensão.

\subsubsection{Segunda dimensão - Separação de proteínas pelo peso molecular}

Primeiramente as tiras são incubadas duas vezes em tampão de equilíbrio (Tris-HCl 50 $\mathrm{mM}$ pH 6,8, uréia $6 \mathrm{M}$, glicerol $30 \% \mathrm{~m} / \mathrm{v}$, SDS $1 \% \mathrm{~m} / \mathrm{v}$, azul de bromofenol 0,002\%), onde a primeira incubação é feita na presença de DTT e a segunda na presença de iodoacetamida, por 15 minutos cada, à temperatura ambiente com agitação leve. Após a etapa de equilíbrio, as tiras foram posicionadas em contato com o gel para iniciar a corrida.

Finalizada a corrida, o gel foi incubado em solução de fixação (etanol 50\%, ácido acético glacial 10\%) por 30 minutos e transferido para a solução de Coomassie blue G-250 coloidal, onde foi incubado por 12 horas. Após este período, os géis foram descorados em uma solução de etanol $20 \%$ por 5 minutos e posteriormente mantidos em água MilliQ.

\subsubsection{Identificação de proteína por espectrometria de massa}

Estes ensaios foram realizados no Laboratório Multiusuários do Instituto Butantan, sob a supervisão do Dr. Daniel Carvalho Pimenta. É colaborador nesses estudos o aluno de Doutorado Douglas Oscar Ceolin Mariano, Programa de Toxinologia, Instituto Butantan, orientado pelo Dr. Daniel C. Pimenta. Fez-se a aplicação das amostras no sistema de massas e a identificação das sequências proteicas de acordo com as massas moleculares obtidas. 
Inicialmente os "spots" pré-selecionados foram recortados e descorados (75 mM de bicarbonato de amônio e 40\% de etanol). As proteínas presentes nos "spots" foram reduzidos com DTT $10 \mathrm{mM}$ durante 30 minutos, à $37^{\circ} \mathrm{C}$; em seguida, os materias foram alquilados com Iodoacetamida $50 \mathrm{mM}$, por um período de 30 minutos, à temperatura ambiente e protegidos da luz. Após esta etapa, o sobrenadante foi removido e os "spots" foram lavados com $25 \mathrm{mM}$ de bicarbonato de amônio. Na etapa de desidratação, o sobrenadante foi novamente removido e a cada 10 minutos, 3 sucessivas lavagens foram realizadas com acetonitrila.

Posteriormente, os "spots" foram secos e reidratados com uma solução de $50 \mathrm{mM}$ de bicarbonato de amônio contendo $40 \mathrm{ng} / \mu \mathrm{L}$ de Tripsina, durante 45 minutos e a $4{ }^{\circ} \mathrm{C}$. Para a digestão das proteínas, o excesso da solução contendo tripsina foi removida e $50 \mathrm{mM}$ de bicarbonato de amônio foi adicionado novamente em cada "spot" em um volume suficiente para os mesmos estar completamente cobertos de solução e incubados a $30{ }^{\circ} \mathrm{C}$ por 18 horas.

Na etapa da extração dos peptídeos dos "spots", após acrescentar uma solução de acetonitrila e 5\% de ácido trifluoroacético, os mesmos foram postos em um banho de ultrassom por 10 minutos. Em seguida, os sobrenadantes foram removidos e guardados. Este procedimento repetiu-se 3 vezes, sendo que os sobrenadantes removidos eram combinados com os respectivos em cada etapa. Por último, repetiu-se o processo de extração de peptídeos, porém, trocando a solução descrita acima por acetonitrila (WESTERMEIER; NAVEN, 2002).

Os materiais oriundos da digestão de cada "spot" foram secos e em seguida analisados através da cromatografia líquida acoplada a espectrometria de massas, utilizando um sistema UFLC binário (20A Prominence, Shimadzu Co., Japan) coplado ao espectrômetro de massas do tipo Electrospray - Ion Trap - Time of Flight (ESI-IT-TOF) (LCMS-8030, Shimadzu Co., Japão). Cada material foi ressuspendido em água contendo 0,1\% Ácido Acético e analisada em uma coluna C18 (Discovery C18, $5 \mu \mathrm{m}, 50 \mathrm{~mm} \times 2.1 \mathrm{~mm}$ ), tendo como solventes (A) Ácido Acético, água (1:999) e (B) Ácido Acético, ACN, água (1:900:99). Por meio de um 
fluxo constante de $0,2 \mathrm{~mL} / \mathrm{min}$, o gradiente variou de 5 a $70 \%$ de solvente $\mathrm{B}$, durante $35 \mathrm{~min}$, a $37{ }^{\circ} \mathrm{C}$, e monitorado a $214 \mathrm{~nm}$ por um detector Shimadzu SPD-M20A PDA.

Logo após a etapa cromatográfica, ocorrem as análises por espectrometria de massas, de acordo com os seguintes parâmetros: a voltagem utilizada da interface foi de $4,5 \mathrm{KV}$ e a voltagem do detector, $1,76 \mathrm{KV}$, com temperatura de $200{ }^{\circ} \mathrm{C}$; a fragmentação foi causada por gás de colisão argônio, com $50 \%$ de energia; e os espectros foram obtidos na faixa de 50 a $2000 \mathrm{~m} / \mathrm{z}$.

O padrão de fragmentação para cada amostra foi processado pelo programa MASCOT (Ion Search) versão in house (versão 2.4.0) (PERKINS et al., 1999) para análises proteômicas e/ou pelo Peaks Studio V7 (MA et al., 2003) para sequenciamento 'de novo' e análises proteômicas e de comparação de sequências. 


\section{RESULTADOS}

O processo de S-glutatiolação e a avaliação da importância dos resíduos de cisteínas glutatioláveis da subunidade $\alpha 5$ do proteassomo tem sido o objeto de estudo deste grupo. Com a identificação das duas cisteínas glutatioláveis (Cys221 e Cys76), construiu-se linhagens com mutações sítio-específicas ( $\alpha 5-\mathrm{C} 221 \mathrm{~S}$ e $\alpha 5-\mathrm{C} 76 \mathrm{~S})$, com as quais começamos a investigar as alterações fenotípicas dessas linhagens causadas por esta mutação. Em seguida, partimos para análises estruturais do proteassomo e, por fim, avaliações bioquímicas com o intuito de justificar as mudanças de fenótipo observadas entre as linhagens.

\subsection{Alterações fenotípicas causada pela mutação sitio-específica}

Primeiramente analisamos a capacidade de crescimento dessas linhagens, seguido de tolerância ao estresse oxidativo e ensaios de longevidade.

A curva de crescimento é obtida com base na determinação espectrofotométrica da Densidade Óptica (O.D) da cultura, medida no comprimento de onda de 600 nm (D.O 600 nm), ao longo do tempo de incubação.

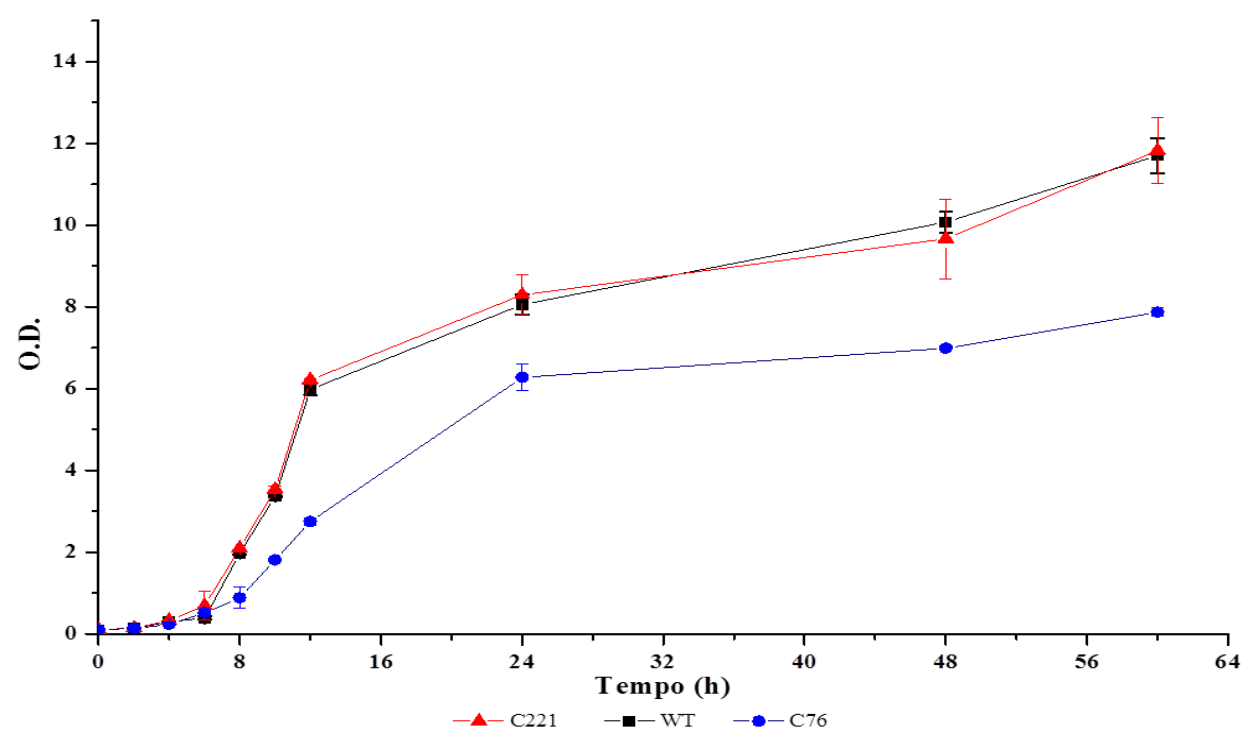

Figura 1 - Curva de crescimento. As células foram inoculadas a O.D 0,1 em meio YPD 4\%. O crescimento foi acompanhado por medições da absorbância de duas em duas horas por 24 horas e após esse período, de doze em doze horas até 60 horas. Os dados mostrados referem-se à média + desvio padrão de três experimentos independentes. 
Durante a fase $\log$ (primeiras 12 horas; reprodução celular bastante ativa, período de crescimento logarítmico), a linhagem mutante C76 apresentou dificuldade no crescimento, enquanto que a linhagem selvagem e a mutante C221 apresentaram um crescimento semelhante. Ao final do ensaio, já em fase estacionária, a linhagem C76 apresentou um crescimento em torno de $40 \%$ menor quando comparada com a linhagem selvagem (Figura 1), ou seja, a ausência da Cys76, consequentemente da glutatiolação deste resíduo de Cys, afetou o crescimento dessa linhagem.

O ensaio de viabilidade celular por diluição seriada teve como objetivo comparar e avaliar a tolerância das linhagens de levedura ao estresse oxidativo submetendo-as a um tratamento com diferentes concentrações de peróxido de hidrogênio $(0.5,0.75,1$ e $2 \mathrm{mM})$.

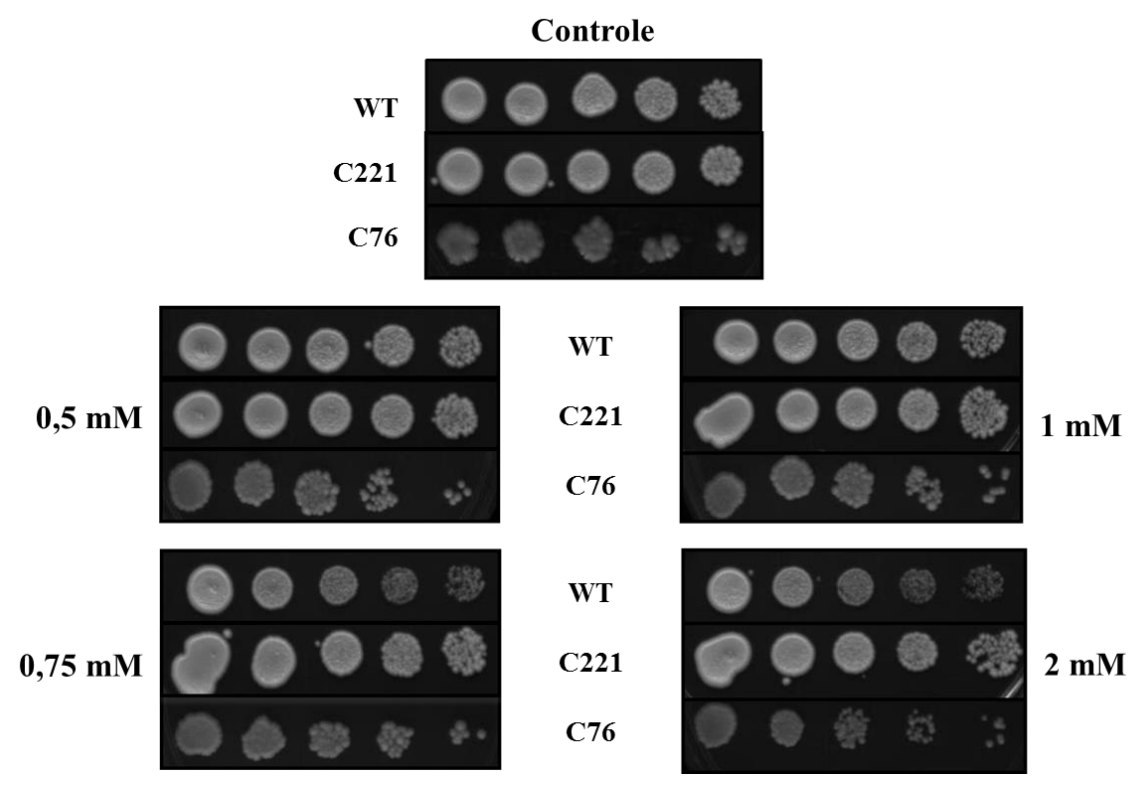

Figura 2. Análise da tolerância ao estresse oxidativo das linhagens de levedura selvagem (WT) e mutantes (C221 e C76). As linhagens selvagem e mutantes C221 e C76 foram crescidas até a fase estacionária em meio YPD $4 \%$ e, então, submetidas à diluição seriada, ou seja, $5 \mu 1$ de cada diluição foram plaqueados em meio YPD sólido contendo diferentes concentrações de peróxido de hidrogênio. As figuras mostradas são representativas de quatro experimentos independentes.

Observamos que a linhagem C221 possui maior resistência ao estresse oxidativo quando comparada a linhagem selvagem (Figura 2). A princípio, esperávamos que a linhagem 
mutante C76 apresentasse uma sensibilidade ao estresse, porém, ela não apresenta uma sensibilidade ao estresse e sim uma dificuldade no crescimento em comparação as demais linhagens como mostrado na curva de crescimento.

O ensaio de envelhecimento cronológico mede o tempo de vida que uma célula consegue sobreviver a partir de uma cultura de células através da capacidade de formação de colônias. Esse resultado é condizente com os resultados anteriores onde, a linhagem C221, que possui maior tolerância ao estresse oxidativo, apresentou maior longevidade em comparação a selvagem, em contrapartida, a linhagem C76, que apresenta dificuldade no crescimento, mostrou um tempo de vida menor (Figura 3).

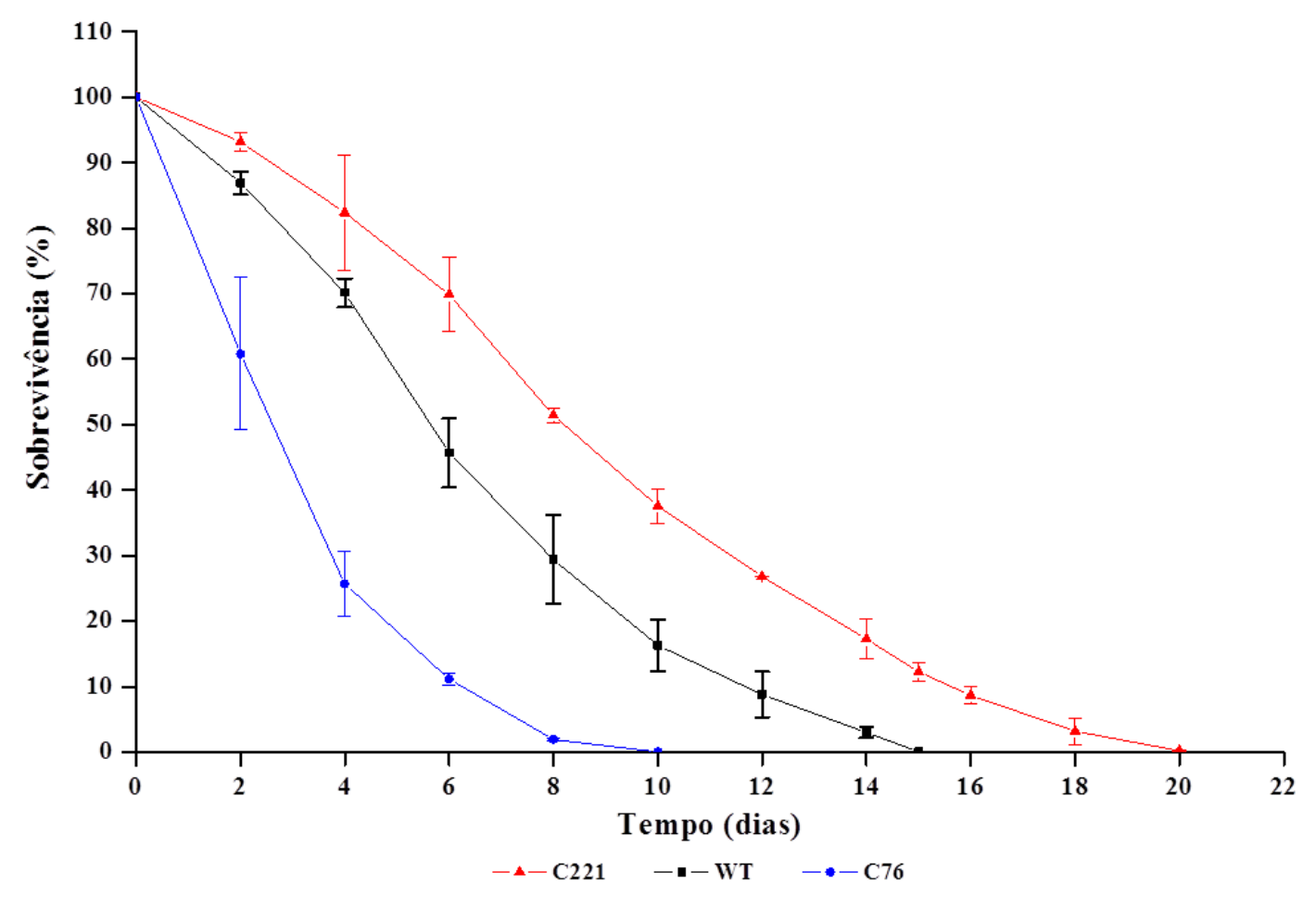

Figura 3 - Ensaio do tempo de vida cronológico. As células foram cultivadas em meio mínimo SDC e crescidas em diferentes intervalos de tempo. As linhagens foram analisadas e avaliadas quanto à habilidade de formação de colônias. Todo o procedimento está descrito em Materiais e Métodos. 
No ensaio de envelhecimento replicativo é avaliada a capacidade da célula-mãe se replicar, ou seja, o ensaio consiste na contagem do número de vezes que uma célula é capaz de gerar uma célula-filha. Esse ensaio foi realizado em colaboração com o Dr. Mário Henrique de Barros do departamento de microbiologia (ICB-USP). Como podemos ver na figura 4, observamos claramente que a linhagem C76 possui menor capacidade de replicação.

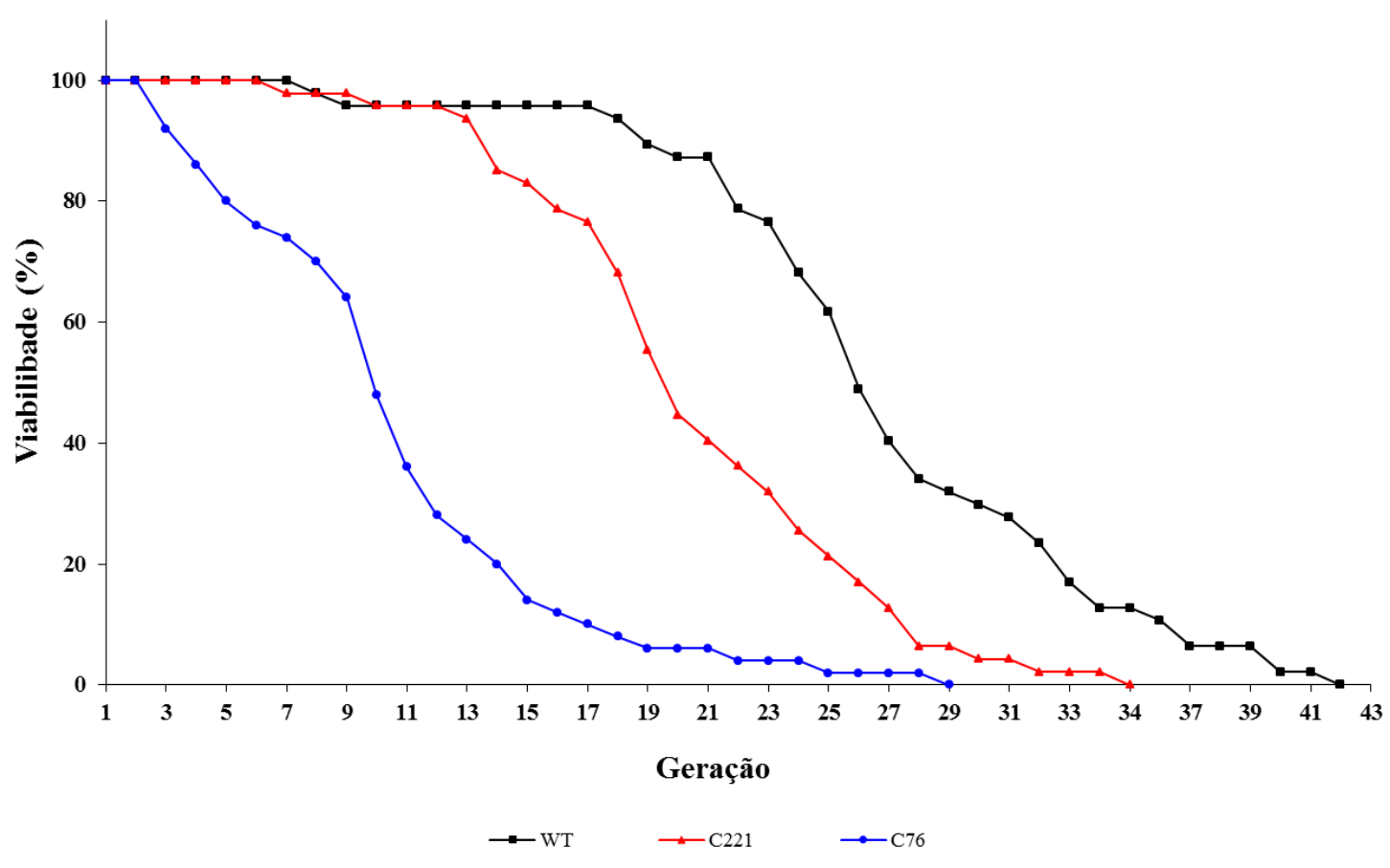

Figura 4 - Ensaio do tempo vida replicativo. O experimento teve início pelo isolamento de 40 células-filhas, também denominadas "virgens", de cada uma das linhagens examinadas. Essas células foram mantidas em meio sólido de YPD. A cada geração observada, as células filhas foram descartadas. Esse procedimento se repetiu até o momento que cessou a replicação: após a $42^{\mathrm{a}}$. Os dados mostrados referem-se a apenas um experimento.

Esse ensaio de envelhecimento replicativo, diferente do envelhecimento cronológico, mostrou que a linhagem com maior capacidade replicativa é a selvagem.

Curiosamente, a linhagem C221 que apresentou tempo de vida cronológico duas vezes maior que a linhagem selvagem, apresenta capacidade replicativa ao redor de $17-18 \%$ menor que a linhagem selvagem, ou seja, quando $100 \%$ de ambas as linhagens deixaram de replicar, a diferença do número de gerações entre as linhagens selvagem e C221 foi de apenas $17 \%$ e, 
quando $50 \%$ das células virgens iniciais deixaram de replicar, a diferença no número de gerações entre as células restantes foi de $18 \%$ entre selvagem e C221. A diferença entre as linhagens selvagem e C221 somente ocorre após a $17^{\text {a }}$ geração, enquanto que, essa diferença se estabelece entre as linhagens WT e C76 logo após a $2^{\mathrm{a}}$ geração.

A conclusão que os experimentos descritos acima nos permitem é de que a linhagem que carrega a mutação $\alpha 5$-C221S apresenta uma resistência ao estresse oxidativo e, o mais surpreendente, um aumento no tempo de vida cronológico. Esse resultado nos levou a investigar uma explicação desse aumento na longevidade causado pela mutação. Inicialmente verificamos a expressão e a concentração do proteassomo 20S e 19S em cada linhagem uma vez que são inúmeros trabalhos na literatura recente que mostram a importância da ativação do proteassomo no aumento da expectativa de vida de várias espécies (CHONDROGIANNNI et al., 2015; KRUEGEL et al., 2011).

\subsection{Não há alteração na expressão e na concentração de proteassomo entre as linhagens selvagem e mutantes.}

Realizamos ensaios para verificar a possibilidade de alguma alteração na concentração e na expressão do proteassomo. Vale ressaltar que, o rendimento das preparações do 20SPT da linhagem C76 é bastante baixo relativamente às preparações a partir das linhagens selvagem e C221. A primeira hipótese que surgiu foi de que a concentração do 20SPT na linhagem C76 fosse menor comparativamente à linhagem selvagem e C221.

No entanto, através de ensaios de imunomarcação verificamos que os níveis do 20SPT, assim como da unidade regulatória 19S, não estão alterados na linhagem C221 e C76 comparativamente à linhagem selvagem (Figura 5). 


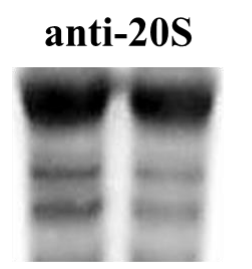

WT $\quad$ C221

anti-20S

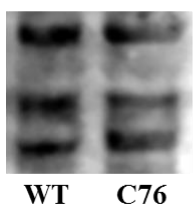

anti-19S

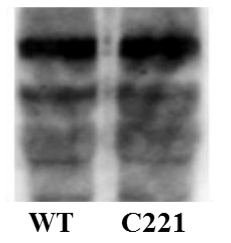

anti-19S

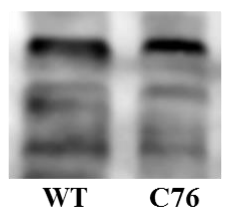

anti-actina

WT C221

anti-actina

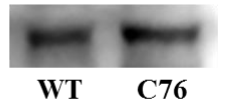

Figura 5 - Imunomarcação com anticorpos anti-20SPT, anti-19SPT e anti-actina. Foram aplicados em SDSPAGE $50 \mu \mathrm{g}$ de extrato celular obtido de células selvagem (WT) e mutantes C221 e C76. Após transferência das amostras para membrana de nitrocelulose foi feita a marcação com os anticorpos indicados. A revelação foi feita por quimioluminescência e a emissão registrada por fotodocumentador. Os dados mostrados são representativos de dois experimentos independentes.

Para confirmar os dados de concentração do proteassomo nestas linhagens, foi feita uma avaliação dos níveis de expressão gênica de uma série de genes que codificam para algumas subunidades do proteassomo $20 \mathrm{~S}$ e $19 \mathrm{~S}$. Estes ensaios foram realizados com a colaboração da Dra. Maria Luiza M. B. de Chaves do departamento de anatomia (ICB-USP) e sua aluna de doutorado Caroline Antunes Lino. Esses resultados, corroborando com os dados de imunomarcação (Figura 5), mostram que não há diferenças significativas nos níveis de expressão dos genes codificantes para subunidades da unidade catalítica 20S, assim como para o gene de uma das subunidades da unidade regulatória 19S, entre as linhagens (Figura 6). Embora exista uma tendência na linhagem C76 à queda da expressão nessas subunidades, essa diminuição não foi estatisticamente significante em nenhuma das medidas. Entretanto, o gene $P U P 2$, o qual codifica para a subunidade $\alpha 5$ e possui as mutações sítio-específicas foi o único que apresentou expressão alterada (Figura 6A). Desconhecemos a razão disso. No entanto, sabemos que para o "assembly" total da unidade catalítica 20S é necessária a experessaão equitativa dos 14 genes que codificam as subunidades do 20SPT, por isso, avaliamos a expressão do gene UMP1 que codifica a chaperona Ump1 responsável pelo "assembly" da unidade 20SPT (Figura 6F). 
A

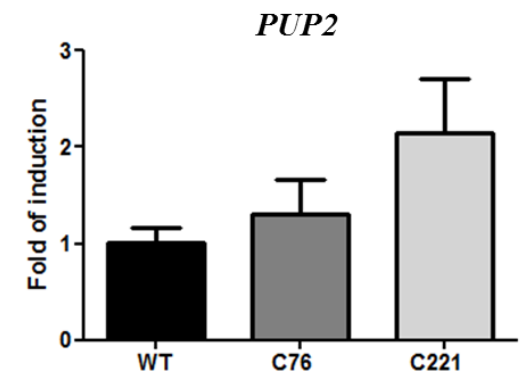

C

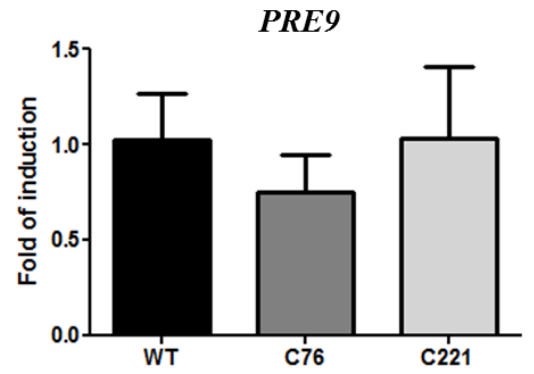

$\mathbf{E}$

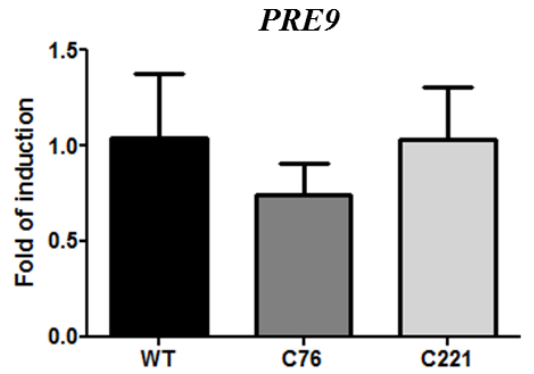

B

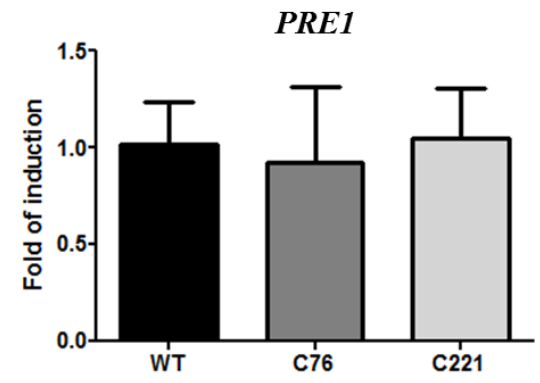

D

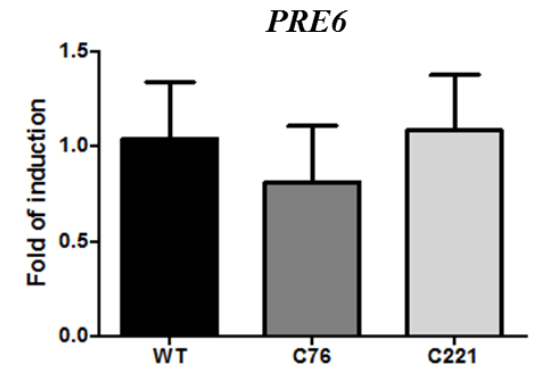

$\mathbf{F}$

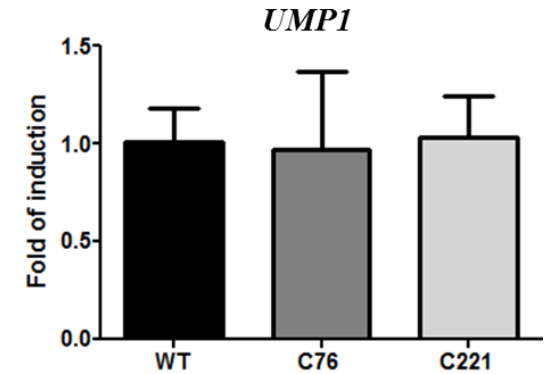

Figura 6 - Expressão gênica de subunidades proteassomais - Avaliação da expressão de genes da unidade catalítica 20SPT foi realizada por RT-PCR como descrito em Materiais e Métodos. Os genes indicados referemse às seguintes subunidades do 20SPT: (A) Subunidade $\alpha 5$; (B) Subunidade $\beta 4$; (C) Subunidade $\alpha 3$ e (D) Subunidade a4; (E) Subunidade ATPásica Rpn1 da unidade regulatória 19SPT; (F) Chaperona Ump1. Os resultados mostrados representam média \pm SD de cinco experimentos independentes.

\subsection{Alterações estruturais e atividade catalítica do proteassomo}

Os experimentos descritos abaixo tiveram por objetivo analisar as formas mutantes do 20SPT relativamente à abertura da câmera e às atividades catalíticas sítio-específica e proteolítica. Para tanto, foram feitas preparações purificadas do 20SPT das respectivas linhagens.

O 20SPT purificado da linhagem C221 e examinado por microscopia eletrônica de transmissão (MET) apresentou alta frequência de formas abertas $(80 \% \pm 3)$ comparativamente 
ao 20SPT selvagem $(65 \% \pm 4)$ enquanto que, o 20SPT purificado da linhagem C76 apresenta alta prevalência de formas fechadas $(30 \pm 2)$. Os dados de MET estão mostrados na figura 7A e 7B. A figura 7C resume os dados quantitativos obtidos na análise de MET relativamente à frequência de formas abertas.

As preparações do 20SPT da linhagem C221 foram tratadas com o redutor tiólico DTT uma vez que, muito provavelmente, o 20SPT mutante $\alpha 5-\mathrm{C} 221 \mathrm{~S}$ possui a Cys76 glutatiolada. De fato o que observamos após tratamento com DTT foi de que a frequência de formas abertas se reduziu para $45 \%$ após o tratamento com DTT (Figura 7B). Esse dado está sendo confirmado por ensaios de espectrometria de massas a partir do isolamento da subunidade $\alpha 5$ após separação do 20SPT em gel 2-DE.
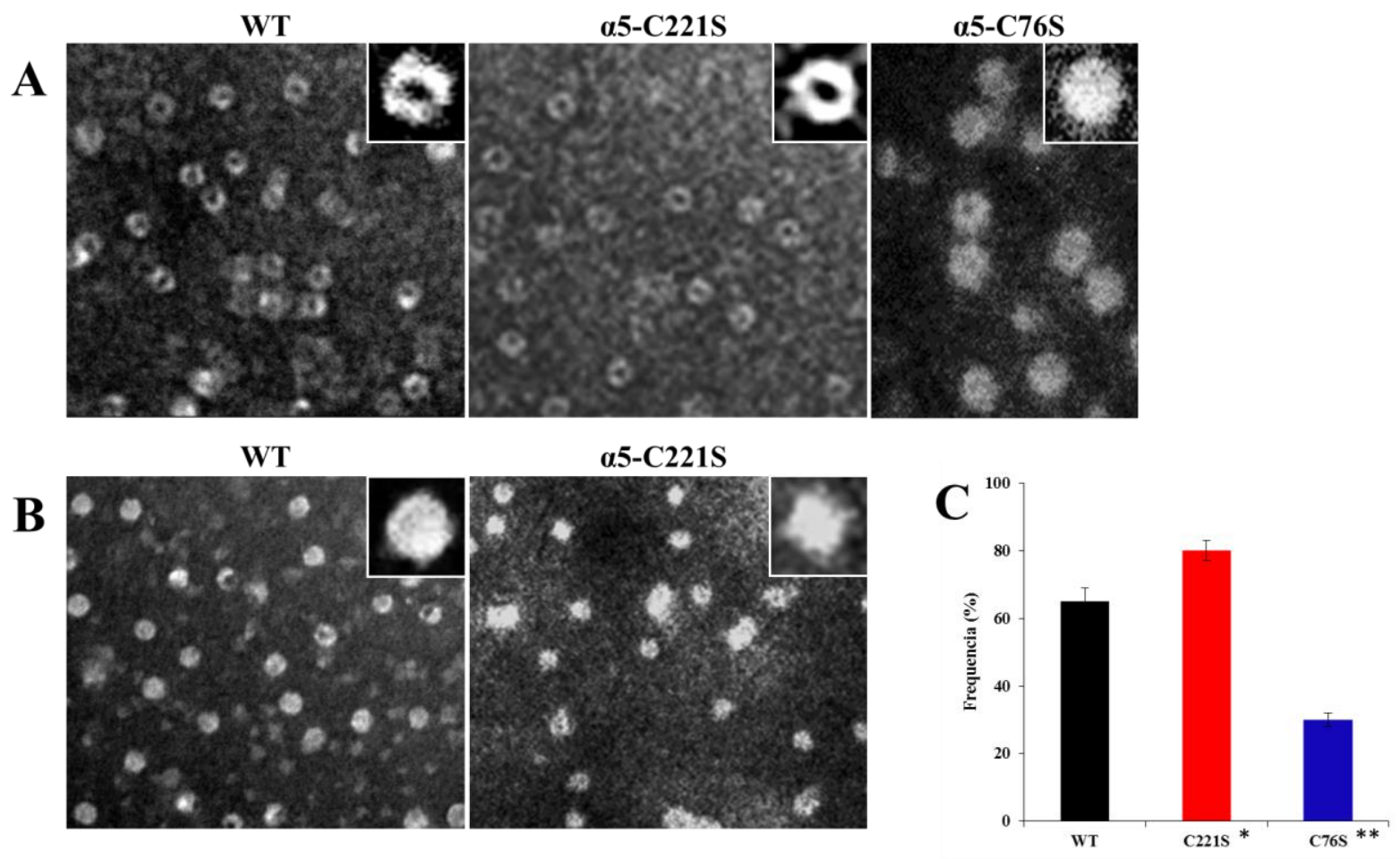

Figura 7 - Avaliação da frequência de formas abertas do 20SPT por microscopia eletrônica de transmissão. (A) Painéis representativos das alíquotas referentes ao 20SPT purificado das linhagens selvagem e mutantes (C221 e C76) analisadas em microtelas coradas negativamente com $2 \%$ de fosfotungstato de potássio. (B) 20SPT purificado das linhagens selvagem e mutantes (C221 e C76) tratadas com DTT. (C) Os painéis obtidos por MET foram utilizados para a contagem manual das formas abertas do 20SPT relativamente ao total de estruturas visualizadas em cada um dos painéis. Os resultados mostrados referem-se à média \pm SD de três experimentos independentes. ${ }^{*} \mathrm{p} \leq 0,004{ }^{*} \mathrm{p} \leq 0,0001$. 
Posteriormente, analisamos as atividades do tipo-quimiotripisina (ChT-L), tripsina (TL) e pós-acídica (PA) do 20SPT das linhagens selvagem e mutante C221. Para isso, diversas preparações do 20SPT $(1 \mu \mathrm{g})$ foram incubados a $37{ }^{\circ} \mathrm{C}$ em tampão $(20 \mathrm{mM}$ Tris/HCl, pH 7.5) na presença ou não de $10 \mathrm{mM} \mathrm{KCl} \mathrm{e/ou} 5 \mathrm{mM} \mathrm{MgCl}_{2}$ ) com $100 \mu \mathrm{M}$ do substrato ChT-L sucLLVY-AMC; $400 \mu \mathrm{M}$ do substrato T-L z-ARR-AMC e $100 \mu \mathrm{M}$ do substrato z-LLE-AMC. Esses dados estão mostrados na Tabela 2 e discutidos abaixo.

Tabela 2 - Atividade sítio-específica de preparações purificadas do 20SPT das linhagens selvagem e C221.

\begin{tabular}{lcc}
\hline & WT & C221S \\
\hline ChT-TL & $70 \pm 13$ & $114 \pm 10,5^{*}$ \\
T-L & $27 \pm 1$ & $29 \pm 1$ \\
PA & $22 \pm 2$ & $32,5 \pm 2^{* *}$ \\
\hline
\end{tabular}

Foi incubado 1-2 $\mu \mathrm{g}$ de 20SPT em tampão Tris $20 \mathrm{mM}$, pH 7,5, a $37{ }^{\circ} \mathrm{C}$. Após a adição dos substratos (descritos no texto acima e em Materiais e Métodos), a emissão da fluorescência foi registrada por 45 min em intervalos de 5 min em espectrofluorímetro a $440 \mathrm{~nm}$ (excitação a $365 \mathrm{~nm}$ ). Os resultados mostrados referem-se à média \pm SD de três experimentos independentes (preparações diversas do 20SPT). Estão expressos em UAF (Unidade Arbitrária de Fluorescência)/ min. Cada ensaio foi realizado em triplicata. ${ }^{*} \mathrm{p} \leq 0,05 * * \mathrm{p} \leq 0,0033$

Quando os ensaios foram realizados apenas em tampão Tris $20 \mathrm{mM}, \mathrm{pH} \mathrm{7,5}$ na presença ou não de $\mathrm{MgCl}_{2} 5 \mathrm{mM}$ a atividade sítio-específica ChT-L do mutante C221S foi maior do que aquela observada nas amostras do 20SPT selvagem: em torno de 40-60\%. A mesma magnitude de ativação foi observada no caso da atividade PA. No entanto, a atividade T-L não variou em relação àquela observada nas preparações do 20SPT selvagem independentemente do tampão utilizado. Interessante observar que na presença de $\mathrm{K}^{+}$ adicionado ao tampão, a ativação do sítio ChT-L no mutante C221S desaparece (dado não mostrado). Essa aparente inibição do sítio ChT-L por íons $\mathrm{K}^{+}$pode estar ocorrendo devido ao efeito alostérico não observado no caso do proteassomo selvagem. 
Também avaliamos a atividade sítio-específica do tipo-quimiotripisina do 20SPT presente no extrato celular total. Observamos uma ligeira queda da atividade catalítica ChT-L na linhagem C221 (Figura 8) tanto na presença quanto na ausência de ATP. A atividade avaliada na presença de ATP refere-se àquela da unidade catalítica $20 \mathrm{~S}$ acoplada a pelo menos uma unidade 19S (da CUNHA et al., 2011; LIU et al., 2006). Provavelmente, a diferença da atividade ChT-L entre os dados obtidos in vitro com preparações purificadas do 20SPT das linhagens selvagem e C221 se deva à presença intracelular de íons K.

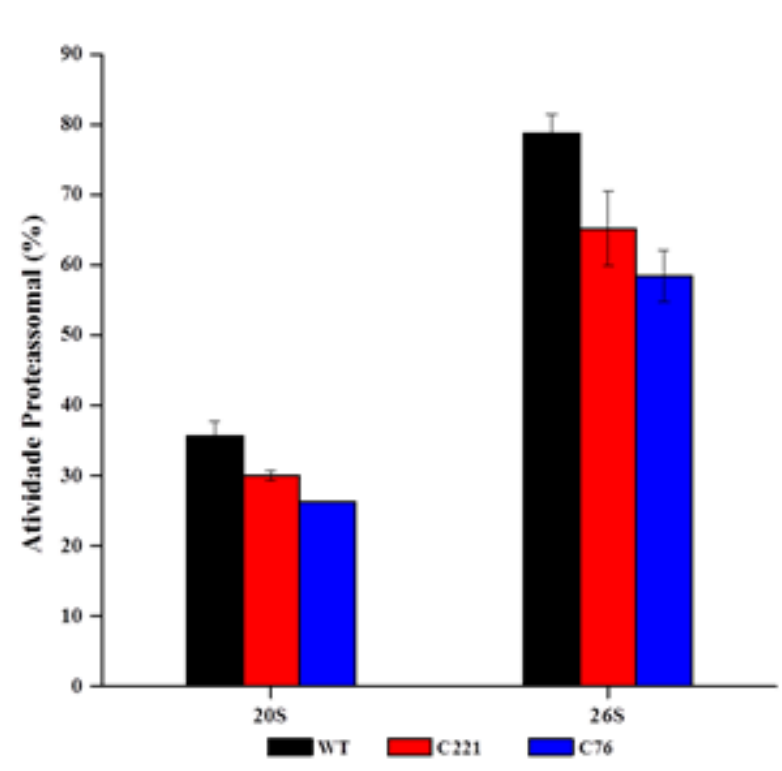

Figura 8 - Ensaio de atividade tipo-quimiotripisina do 20SPT e 26SPT no extrato celular total. Foram incubadas $60 \mu \mathrm{g}$ do extrato celular com $50 \mu \mathrm{M}$ de substrato peptídico em tampão $20 \mathrm{mM}$ Tris- $\mathrm{HCl} \mathrm{pH} \mathrm{7,5}$ contendo $10 \mathrm{mM} \mathrm{KCl}$ e $5 \mathrm{mM} \mathrm{MgCl}$ a $37{ }^{\circ} \mathrm{C}$. Para a atividade do $26 \mathrm{~S}$ foi utilizado o mesmo protocolo, mas na presença de $5 \mathrm{mM}$ de ATP adicionado desde o início da lise celular. A emissão da fluorescência foi registrada por $45 \mathrm{~min}$ em intervalos de $5 \mathrm{~min}$ em espectrofluorímetro a $440 \mathrm{~nm}$ (excitação a $365 \mathrm{~nm}$ ). Os resultados mostrados referem-se à média \pm SD de dois experimentos realizados em triplicata

Para analisar a atividade proteolítica do proteassomo, realizamos o ensaio de proteólise in vitro. Utilizamos para esse ensaio a Grx2 (Glutarredoxina 2), $\beta$-Cas ( $\beta$-caseína), que sabidamente são hidrolisadas pelo 20SPT de forma ubiquitina-independente como substrato (SILVA et al., 2012) e testamos também a $\alpha$-Syn ( $\alpha$-sinucleína). A degradação destas proteínas e o surgimento de fragmentos peptídicos foram acompanhados por gel SDSPAGE. 


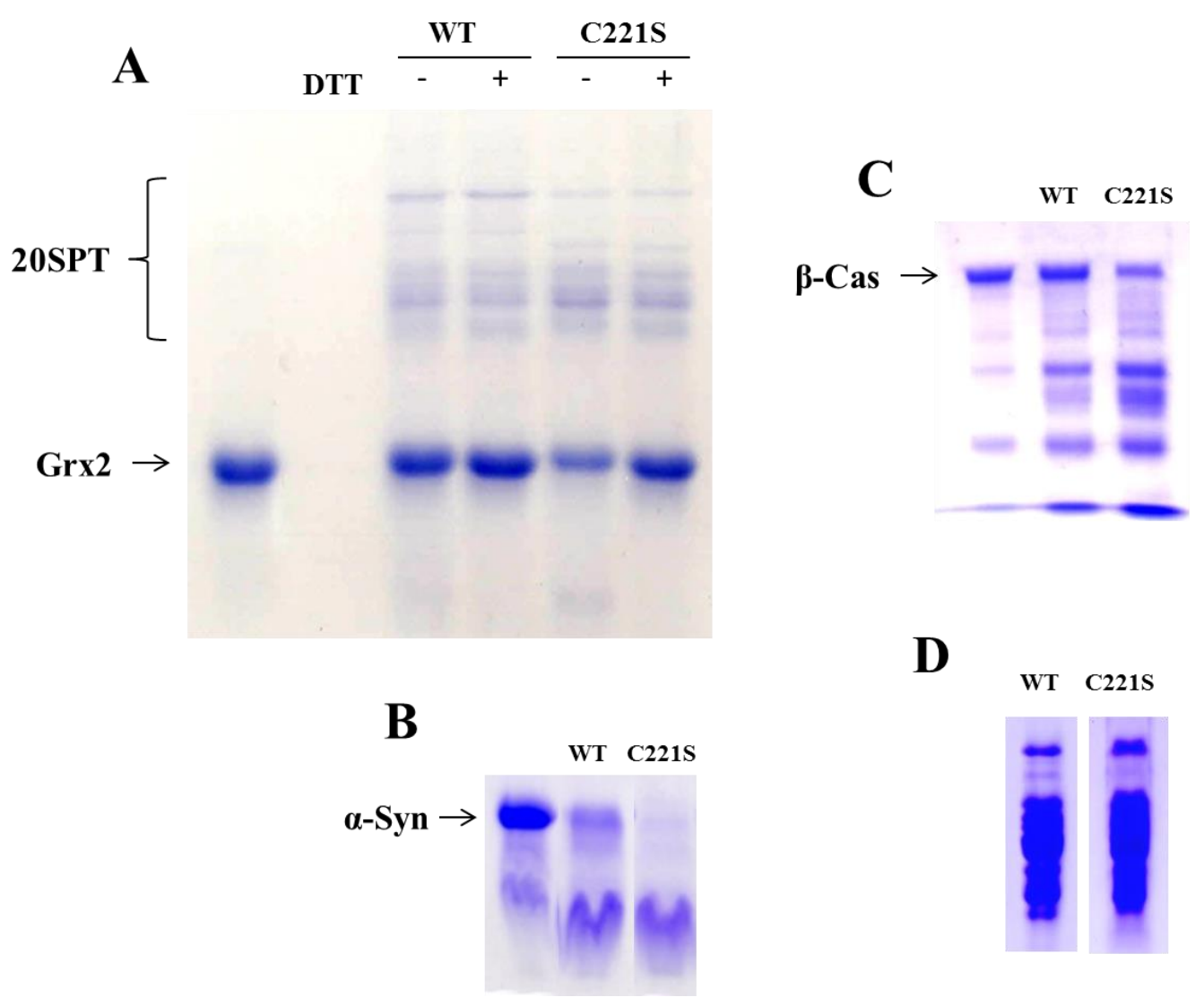

Figura 9 - Capacidade proteolítica do 20SPT selvagem e mutante C221S. (A) Foram incubadas $5 \mu \mathrm{g}$ de preparações de proteassomo selvagem e mutante $\alpha 5-\mathrm{C} 221 \mathrm{~S}$ com $15 \mu \mathrm{g}$ de Grx 2 durante 120 minutos, na presença e na ausência de DTT como indicado; (B) $5 \mu \mathrm{g}$ de $\alpha$-sinucleína foram incubadas com $20 \mu \mathrm{g}$ das preparações de 20SPT durante 120 minutos. (C) $20 \mu \mathrm{g}$ de $\beta$-caseína foram incubadas com $5 \mu \mathrm{g}$ dos proteassomos purificados durante 15 minutos; As incubações foram realizadas à $37^{\circ} \mathrm{C}$ sob agitação a cada 5 min. As amostras de B e C foram filtradas em microfiltros Microcon-100 (Millipore) para remover o 20SPT. Os filtrados foram misturados ao tampão de amostra contendo $10 \mathrm{mM}$ DTT e aplicados em SDS-PAGE 12,5-15\%. Os resultados mostrados são representativos de ensaios realizados em tampão $20 \mathrm{mM}$ Tris pH 7,5 acrescido de (A) $20 \mathrm{mM} \mathrm{KCl}$ e $5 \mathrm{mM} \mathrm{MgCl}_{2}$; (B) $5 \mathrm{mM} \mathrm{MgCl} 2$ e (C) sem adição iônica. Os géis mostrados em $\mathrm{D}$ são representativos de preparações do 20SPT e servem de controle da pureza das preparações obtidas. Preparações com o mesmo grau de pureza foram utilizadas para as medidas das atividades sítio-específicas como mostrado na Tabela 2.

Esse ensaio mostrou que o proteassomo C221S degrada com maior eficiência o substrato proteicos quando comparada ao proteassomo selvagem (Figura 9). Da mesma forma que o proteassomo selvagem diminui levemente a sua capacidade de degradação na presença de DTT, o proteassomo mutante também é afetado (Figura 9A). Sendo assim um indicativo de que o 20SPT da linhagem C221 responde ao agente redutor de tióis DTT. A degradação proteica na presença de DTT diminuiu devido à redução de resíduos de Cys glutatiolados e 
consequente fechamento da câmara catalítica. Diferentemente da atividade sítio-específica do tipo ChT-L que no caso do 20SPT C221S é inibida por íons $\mathrm{K}^{+}$, a atividade proteolítica não foi inibida na presença de $\mathrm{KCl}$ (Figura 9A). A degradação de caseína também foi feita na presença de $\mathrm{KCl}$ e não observamos queda de degradação comparativamente à degradação na ausência de $\mathrm{KCl}$ (dados não mostrados). Portanto, muito provavelmente, o $\mathrm{K}^{+}$promove alteração alostérica no sítio $\beta 5$ (atividade ChT-L) enquanto que o aumento da velocidade proteolítica observada nos ensaios mostrados na figura 9 se deva exclusivamente à abertura da câmera catalítica do 20SPT.

\subsection{Avaliação dos parâmetros redox}

Ainda com o intuito de elucidar o mecanismo do aumento do tempo de vida cronológico da linhagem C221, iniciamos ensaios bioquímicos onde foram avaliados os parâmetros relacionados ao metabolismo redox nas linhagens aqui estudadas, como: conteúdo de algumas enzimas anti-oxidantes, a capacidade de remover $\mathrm{H}_{2} \mathrm{O}_{2}$ e a razão GSH/GSSG. Em relação aos danos oxidativos, avaliamos o conteúdo de proteínas oxidadas pela determinação de carbonila proteica (parâmentro de oxidação proteica bastante utilizado) e a formação de agregados proteicos.

Através do ensaio de imunomarcação verificamos o conteúdo algumas enzimas antioxidantes nas linhagens mutantes e selvagem. Novamente, não encontramos nenhuma alteração significativa que explique as diferenças fenotípicas observadas entre as linhagens (Figura 10). 
A

\section{anti-Trr1 \\ anti-Trr2 \\ anti-Grx1 \\ anti-Prx1 \\ anti-Tsa1}

\section{WT \\ C221}
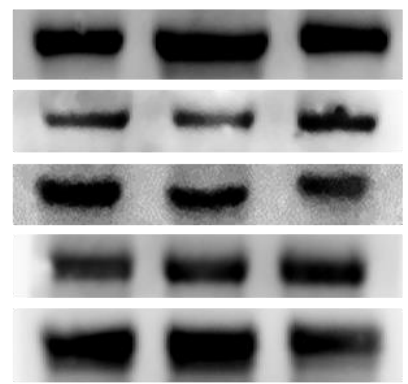

B

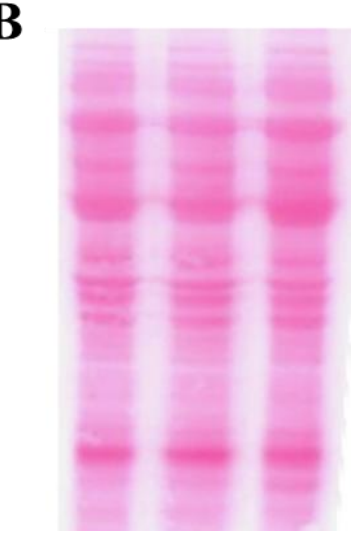

Figura 10 - Conteúdo de enzimas anti-oxidantes nas linhagens. Foram aplicadas $30 \mu \mathrm{g}$ de extrato celular em gel SDS-PAGE 12,5\% - 15\%. Após transferência das amostras para membrana de nitrocelulose foi feita a marcação com os anticorpos indicados (A). A revelação foi feita por quimioluminescência e a emissão registrada por foto documentador. (B) Para o controle de loading as membranas foram previamente coradas com Ponceau Red. Os dados mostrados são representativos de três experimentos independentes.

A escolha dessas enzimas para serem avaliadas foi feita tomando por base o papel funcional de cada uma delas e a disponibilidade de anticorpos. Vale ressaltar que todos os anticorpos utilizados são poli-clonais, produzidos em coelho pelo nosso grupo de pesquisa. São altamente específicos, pois são sempre testados em extrato celular de leveduras que apresentam deleção do gene codificador da proteína em questão. Este é um controle que fazemos de todos os anticorpos para proteínas de levedura produzidos. Em relação à função das proteínas avaliadas, como segue:

Tsa1: peroxidase citoplasmática muito abundante e responsável pela remoção principalmente do peróxido inorgânico $\left(\mathrm{H}_{2} \mathrm{O}_{2}\right)$ (NETTO et al., 2007)

Prx1: peroxidase mitocondrial também responsável pela remoção do $\mathrm{H}_{2} \mathrm{O}_{2}$ (TOLEDANO et al., 2013);

Grx1: oxidoredutase que possivelmente tenha atividade desglutatioladora de sulfetos mistos proteicos (COLLINSON et al., 2002);

Trr1 e Trr2: tiorredoxinas redutases citoplasmática e mitocondrial, respectivamente. Tais proteínas são responsáveis pela reciclagem das oxidoredutases tiorredoxinas 1 e 2 (Trx1 e Trx2) citoplasmáticas e pela tiorredoxina 3 (Trx3) mitocondrial (KUMAR et al., 2011; LE 
MOAN et al., 2006,). Ambas Trx 1 e 2 são oxidoredutases capazes de desglutatiolizar o 20SPT (SILVA et al., 2007). A GSH livre está presente na célula principalmente em sua forma reduzida. A resistência de muitas células contra o estresse oxidativo está associada com os elevados níveis intracelulares de glutationa em sua forma reduzida. O estresse oxidativo pode causar mudanças no estado redox da glutationa aumentando a formação de glutationa oxidada. Sendo que a capacidade redutora intracelular depende da razão entre formas reduzida e oxidada da glutationa (GSH/GSSG). Essa razão é um parâmetro crítico e determinante do estado redox intracelular (MELLO et al., 2013). Dessa forma determinamos essa razão nas linhagens aqui estudadas com o objetivo de avaliar se elas possuem condições redox diversas (Tabela 3).

Tabela 3 - Razão GSH/GSSG e capacidade de remover $\mathrm{H}_{2} \mathrm{O}_{2}$ das linhagens selvagem e mutantes.

\begin{tabular}{lccc}
\hline & WT & C221 & C76 \\
\hline${ }^{\mathbf{1}}$ GSH & $658 \pm 54$ & $509 \pm 49^{*}$ & $545 \pm 41,5^{* *}$ \\
${ }^{\mathbf{1}}$ GSSG (nmoles/g pellet) & $30 \pm 2$ & $15 \pm 1.5$ & $15 \pm 0,5$ \\
GSH/GSSG & $22 \pm 3$ & $34 \pm 3$ & $36 \pm 3,5$ \\
${ }^{\mathbf{2}}$ Atividade de Remoção de $\mathbf{H}_{\mathbf{2}} \mathbf{O}_{\mathbf{2}}$ & $21,5 \pm 4$ & $19,5 \pm 6$ & $15 \pm 1 * *$ \\
${ }^{\mathbf{3}}$ Atividade da GR & $54 \pm 2$ & $34 \pm 1$ & $33 \pm 0$
\end{tabular}

Os resultados mostrados representam a média \pm desvio padrão e estão expressos como ${ }^{1}$ nmoles $/ g$ pellet; ${ }^{2}$ Unidades Arbitrárias de Fluorescência (UAF) / g pellet e ${ }^{3}$ Absorbância $412 \mathrm{~nm} \times 10^{3} \mathrm{p} \leq 0,05 * * \mathrm{p} \leq 0,011$

Como observado, houve aumento bastante significativo da razão GSH/GSSG nas linhagens mutantes. Essa diferença pode ser devido a menor concentração da glutationa total e não ao aumento de GSH (forma reduzida). Notamos também que houve queda de glutationa total $(\mathrm{GSH}=\mathrm{GSSG})$ nas linhagens mutantes. Essa queda pode ser devido a alterações de síntese de glutationa ou a sua incorporação em proteínas, ou seja, aumento de glutatiolação proteica. No entanto, de acordo com o ensaio de imunomarcação mostrado na figura 11, observamos que não houve alteração do conteúdo de proteínas glutatioladas. Observou-se ainda que o conteúdo de GSSG diminuiu nas linhagens mutantes. Esse fato pode ser devido à 
diminuição do conteúdo de glutationa total ou ao aumento da atividade de glutationa redutase (GR) nessas linhagens. Como mostrado, a atividade de GR foi semelhante entre as mutantes, porém ligeiramente diminuída em relação à atividade de linhagem selvagem. Podemos concluir que, de fato o aumento da razão GSH/GSSG é devido a menor concentração de glutationa total e não pelo aumento da atividade da GR.
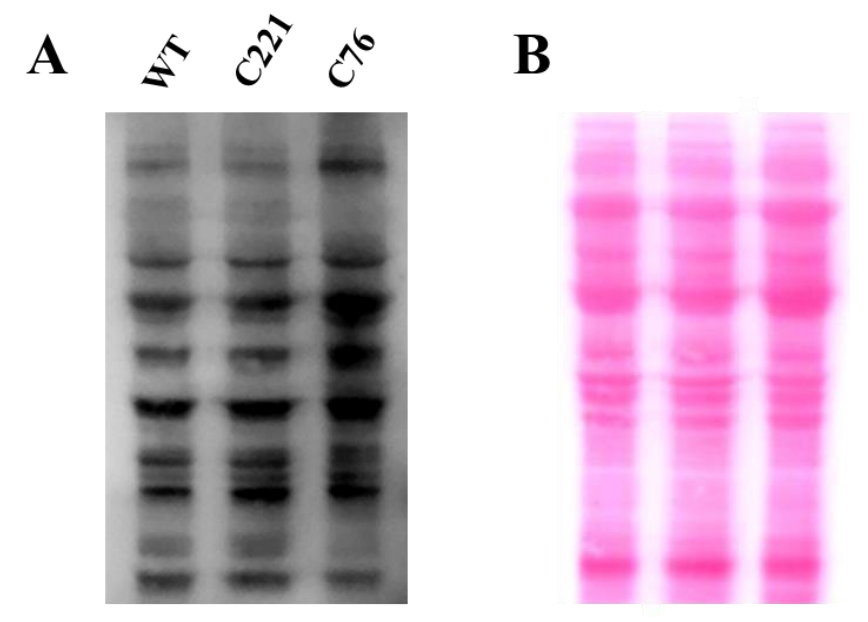

Figura 11 - Conteúdo de proteínas glutatioladas nas linhagens. Foram aplicadas $30 \mu \mathrm{g}$ de extrato celular em gel SDS-PAGE 12,5\%. (A) Após transferência das amostras para membrana de nitrocelulose foi feita a marcação com o anti-GSH. A revelação foi feita por quimioluminescência e a emissão registrada por foto documentador. (B) Para o controle de loading as membranas foram previamente coradas com Ponceau Red.

Visto que $\mathrm{o} \mathrm{H}_{2} \mathrm{O}_{2}$ tem papel central na geração de espécies reativas de oxigênio intracelularmente, analisamos a atividade de remoção de peróxido de hidrogênio $\left(\mathrm{H}_{2} \mathrm{O}_{2}\right)$ nessas linhagens. A linhagem C76S mostrou ligeiro aumento na capacidade de remover $\mathrm{H}_{2} \mathrm{O}_{2}$ quando comparada com a WT.

Avaliamos também a formação intracelular de proteínas carboniladas que representa a mais importante modificação oxidativa de proteínas (DEMASI et al., 2003). A análise do conteúdo intracelular de proteínas oxidadas mediante estresse oxidativo mostrou uma maior formação de proteínas carboniladas nas linhagens mutantes quando comparadas com a linhagem selvagem (Figura 12). Esse resultado já era esperado na C76 por ser uma linhagem 
com dificuldade no crescimento e por possuir, em sua maioria, proteassomos fechados (Figura 7), entretanto, o ligeiro aumento de proteínas oxidadas na linhagem C221 não era esperado.
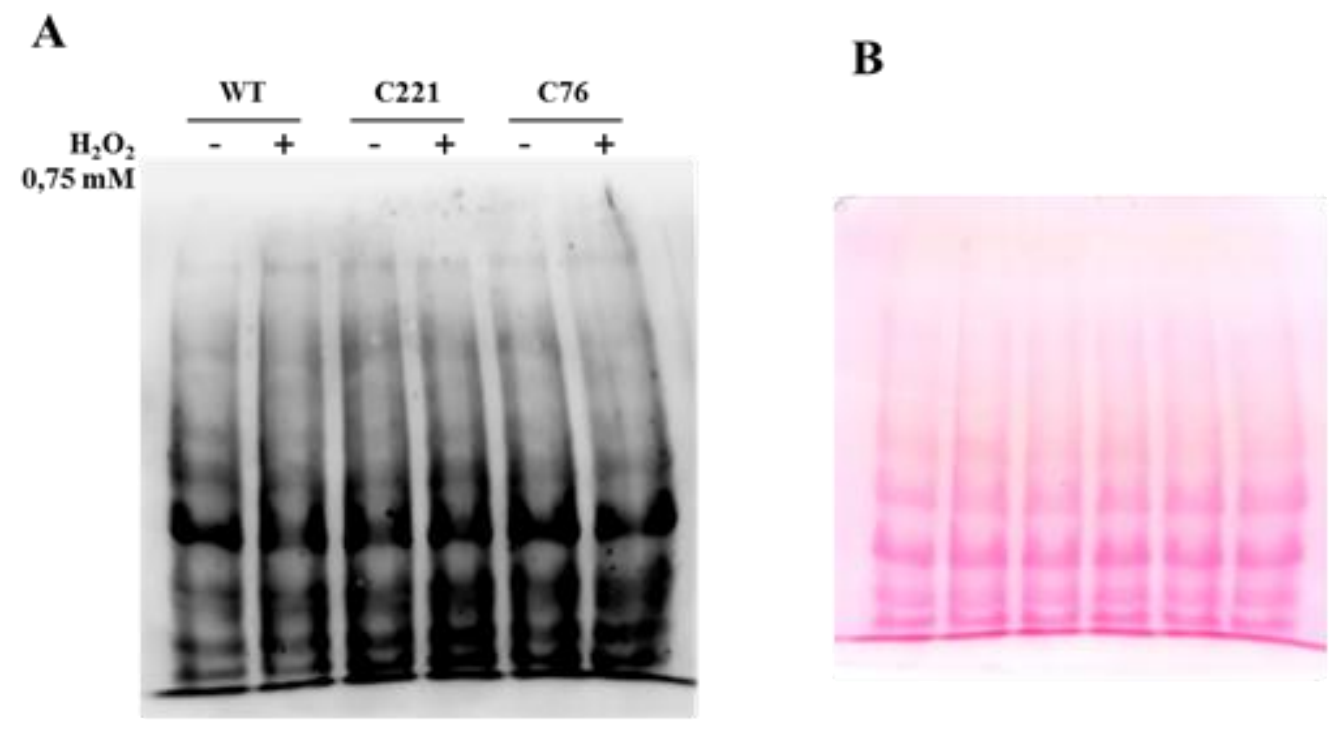

Figura 12 - Conteúdo de proteínas oxidadas nas linhagens. Foram incubados $75 \mu \mathrm{g}$ de extrato celular com 40 $\mu \mathrm{l}$ de DNPH $20 \mathrm{mM}$ e $29 \mu \mathrm{l}$ de SDS $24 \%$ por 30 minutos protegido da luz. Em seguida, $60 \mu \mathrm{l}$ de Sol B (Tris-HCl $2 \mathrm{M}, 30 \%$ de glicerol, $19 \%$ de b-mercaptoetanol) foram adicionadas a mistura. Alíquotas de $30 \mu \mathrm{l}$ mais 7,5 $\mu \mathrm{l}$ de tampão de amostra foi aplicada em gel SDS-PAGE $8.5 \%$, seguido de transferência em membrana de nitrocelulose. (A) Membrana marcada com anti-DNP. (B) Membrana corada com Ponceau red como controle de loading. Os resultados mostrados são representativos de quatro experimentos independentes.

A C221 é uma linhagem que possui, em sua maioria, formas abertas de proteassomo, maior tolerância ao estresse oxidativo, aumento do tempo de vida cronológico e, portanto, esperávamos que ela tivesse maior capacidade de remover proteínas oxidadas. Concluímos que essa linhagem parece se adaptar/suportar grandes quantidades de proteínas oxidadas, no entanto desconhecemos a razão do aumento do conteúdo de proteínas oxidadas nessa linhagem.

Posteriormente, examinamos a produção de agregados proteicos nessas linhagens. $\mathrm{O}$ isolamento de agregados proteicos está descrito em Materiais e Métodos e foi acompanhado por gel SDS-PAGE, onde deparamos com um aumento de agregados na linhagem C221 em comparação a linhagem WT (Figura 13). Esse resultado, aparentemente controverso uma vez 
que a literatura ressalta a importância da manutenção da integridade proteica para a homeostase celular, sendo a prevenção de agregação proteica desejável para promover longevidade (KNOWLES et al., 2014; HIPP et al., 2014), está, no entanto, de acordo com dados mais recentes da literatura que têm questionado a agregação proteica como fenômeno deletério (TORET-ESCUSA et al., 2013). Diferentemente, alguns grupos de pesquisa têm demonstrado que a agregação proteica pode ser um fenômeno regulado intracelularmente e sua produção seria para evitar instabilidade mais ampla do conteúdo proteico intracelular (WALTHER et al., 2015).

$\mathbf{A}$

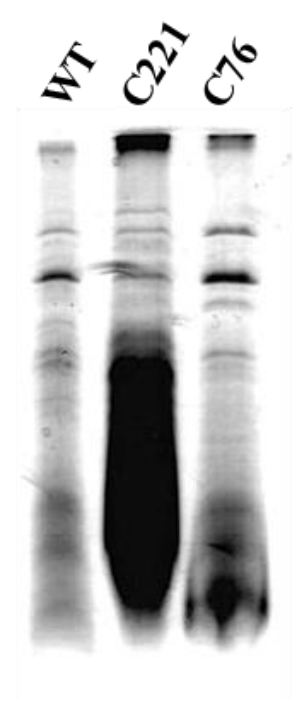

\section{B}

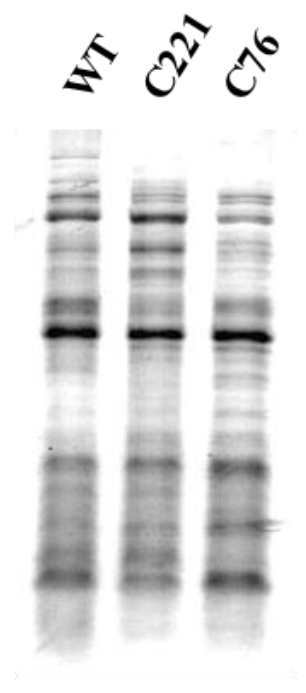

Figura 13 - Conteúdo intracelular de agregados proteicos. Após a lise celular, o material agregado foi separado por centrifugação. Os agregados (A) e o extrato total (B) foram aplicados em gel SDS-PAGE 15\% e por fim corados com comassie blue. A linhagem C221 apresentou maior conteúdo de agregados proteicos. Os géis apresentados são representativos de dois experimentos independentes feitos em duplicata.

Com base nessas recentes interpretações sobre agregação proteica, fizemos a análise por espectrometria de massas do conteúdo dos agregados encontrados na linhagem C221 comparativamente à linhagem selvagem. Esses dados estão mostrados na Tabela 4 e discutidos no próximo item. 
$\mathbf{A}$

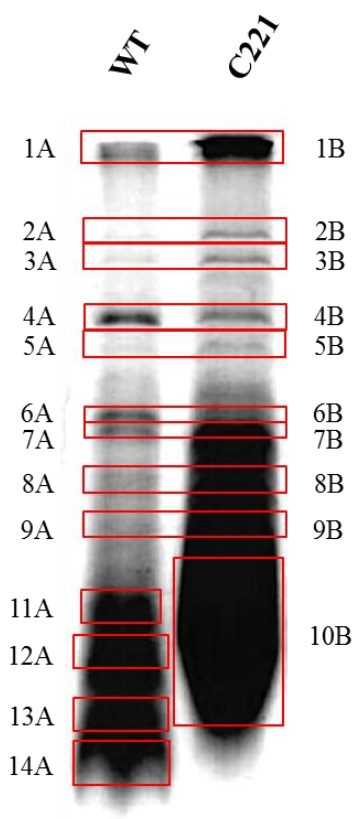

B

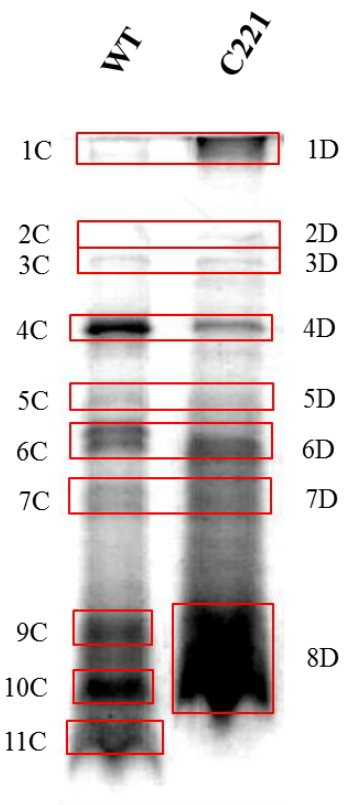

Figura 14 - Identificação de proteínas. Os retângulos vermelhos indicam as bandas dos géis selecionadas e cortadas para análise por espectrometria de massa para a identificação das proteínas. As duas preparações mostradas foram obtidas a partir de massa proteica (A) da proteína total e (B) da proteína total.

Tabela 4 - Proteínas identificadas nos agregados proteicos das linhagens de Saccharomyces cerevisiae selvagem e na mutante C221.

\begin{tabular}{|c|c|c|c|}
\hline Banda & Cód. da Proteína & Proteína & Via \\
\hline $\mathbf{1 A}$ & P25619 & Hsp30 & Proteína de choque térmico \\
\hline $2 \mathrm{~A}$ & $*$ & $*$ & $*$ \\
\hline 3A & $*$ & $*$ & $*$ \\
\hline $4 \mathrm{~A}$ & P02994 & Fator de Elongação 1-alpha & Síntese proteica \\
\hline $\mathbf{5 A}$ & P00358 & Gliceraldehide-3-fosfato desidrogenase 2 & Gliconeogênese e Glicólise \\
\hline 6A & P02995 & Fator de Elongação 1-alpha & Síntese proteica \\
\hline 7A & P05748 & $60 \mathrm{~S}$ ribosomal protein $\mathrm{L} 15-\mathrm{A}$ & Síntese proteica \\
\hline $\mathbf{8 A}$ & $*$ & $*$ & $*$ \\
\hline 9A & P02995 & Fator de Elongação 1-alpha & Sintese proteica \\
\hline $\mathbf{1 1 A}$ & P00549 & Piruvato quinase 1 & Ciclo do ácido cítrico \\
\hline $12 \mathrm{~A}$ & P00549 & Piruvato quinase 1 & Ciclo do ácido cítrico \\
\hline \multirow[t]{4}{*}{$13 \mathrm{~A}$} & P00330 & Alcool desidrogenase 1 & Glicólise \\
\hline & P00549 & Piruvato quinase 1 & Ciclo do ácido cítrico \\
\hline & P00358 & Gliceraldeido 3 fosfato desidrogenase 2 & Glicólise \\
\hline & P00560 & Fosfoglicetaro quinase & Glicólise \\
\hline \multirow[t]{3}{*}{$14 \mathrm{~A}$} & P00330 & Alcool desidrogenase 1 & Glicólise \\
\hline & P00549 & Piruvato quinase 1 & Ciclo do ácido cítrico \\
\hline & P06169 & Piruvato descarboxilase isozima 1 & Fermentação alcoolica \\
\hline
\end{tabular}


P00560

P00360

Q3E7X9

1B

2B

3B

4B

5B

$6 B$

8B

9B

10B

1C

2C

3C

4C

$5 \mathrm{C}$

6C

7C

9C

10C

P00549

P06169

11C

P00330

P06169

P00560

P00549

1D

P25619

P39003

P02994

Q12117

P38695

2D

P32316

3D
Fosfoglicetaro quinase

Gliceraldeido 3 fosfato desidrogenase 1

Proteina ribossomal 40S S28-A

$$
\begin{aligned}
& * \\
& * \\
& * \\
& * \\
& *
\end{aligned}
$$

Fator de Elongação 1-alpha

40S ribosomal protein S2

60S ribosomal protein L15-A

Fator de Elongação 1-alpha

Proteína LSP1

Proteina ribossomal 60S L9-B

Proteina ribossomal 60S L10

Proteina ribossomal 60S L8-A

Proteina ribossomal 60S L16-B

Proteina ribossomal 40S S9-B

Proteina ribossomal 60S L18-A

Piruvato descarboxilase isozima 1

$$
\text { Hsp30 }
$$

$*$

$*$

$*$

Fator de Elongação 1-alpha

Fator de Elongação 1-alpha

Piruvato quinase 1

Piruvato descarboxilase isozima 1

Alcool desidrogenase 1

Piruvato descarboxilase isozima 1

Fosfoglicetaro quinase

Piruvato quinase 1

Hsp30

Transportador de glicose de alta afinidade HXT6

Fator de Elongação 1-alpha

Proteina MRH1

Transportador de glicose HXT5

Acetil-CoA hidrolase

Dihidrolipoamida desidrogenase
Glicólise

Glicólise

Síntese proteica

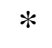

$*$

$*$

$*$

$*$

Síntese proteica

Síntese proteica

Síntese proteica

Síntese proteica

Proteínas de ligação

Síntese proteica

Síntese proteica

Síntese proteica

Síntese proteica

Síntese proteica

Síntese proteica

Fermentação alcoolica

Proteína de choque térmico

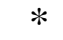

$*$

$*$

Síntese proteica

Síntese proteica

*

*

Ciclo do ácido cítrico

Fermentação alcoolica

Glicólise

Fermentação alcoolica

Glicólise

Ciclo do ácido cítrico

Proteína de choque térmico

Transporte de Hexose

Síntese proteica

Proteina ribossomal mitocondrial

Transporte de Hexose

Ciclo do ácido cítrico

Ciclo do ácido cítrico 


$\begin{array}{cccc} & \text { P02994 } & \text { Fator de Elongação 1-alpha } & \text { Síntese proteica } \\ \text { 4D } & \text { P02994 } & \text { Fator de Elongação 1-alpha } & \text { Síntese proteica } \\ \text { 5D } & \text { P02994 } & \text { Fator de Elongação 1-alpha } & \text { Síntese proteica } \\ & \text { P0CX35 } & \text { Proteina ribossomal 40S S4-A } & \text { Síntese proteica } \\ \text { 6D } & \text { P05748 } & \text { Proteina ribossomal 60S L15-A } & \text { Síntese proteica } \\ \text { 7D } & \text { P0CX49 } & \text { Proteina ribossomal 60S L18-A } & \text { Síntese proteica } \\ & \text { P05755 } & \text { Proteina ribossomal 40S S9-B } & \text { Síntese proteica } \\ & \text { P02994 } & \text { Fator de Elongação 1-alpha } & \text { Síntese proteica } \\ \text { 8D } & * & * & *\end{array}$

As bandas mostradas na Figura 14 foram digeridas e posteriormente analisadas por espectrometria de massas de acordo com o protocolo descrito em Materiais e Métodos. Os dados mostrados são a somatória de bandas identificadas nos dois experimentos independentes. *Proteína não identificada

Avaliamos, ainda, o conteúdo de proteínas poli-ubiquitinadas e, como mostrado na figura 15 , observamos um pequeno aumento de proteínas poli-ubiquitinadas na linhagem C221 e uma diminuição na linhagem C76 em comparação a WT.

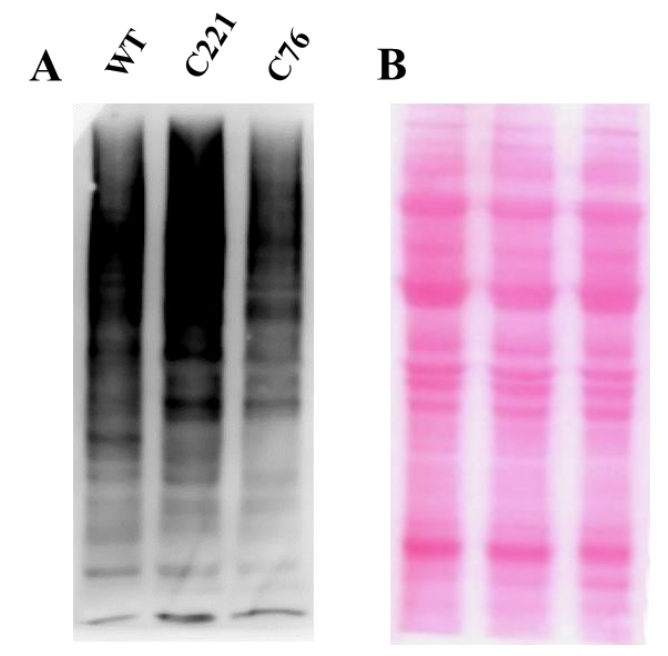

Figura 15 - Conteúdo de proteínas poli-ubiquitinadas nas linhagens. Foram aplicadas $30 \mu \mathrm{g}$ de extrato celular em gel SDS-PAGE 8,5\%. (A) Após transferência das amostras para membrana de nitrocelulose foi feita a marcação com o anti-ubiquitina. A revelação foi feita por quimioluminescência e a emissão registrada por foto documentador. (B) Para o controle de loading as membranas foram previamente coradas com Ponceau Red.

Esse aumento de proteínas poli-ubiquitinadas na linhagem C221 pode ser justificada devido à diminuição de degradação via proteassomo 26S, ou seja, essa linhagem possui em sua maioria formas abertas de proteassomo $20 \mathrm{~S}$ e consequentemente menor capacidade de se 
acoplar com a unidade regulatória 19S para formar o complexo 26S. Esta é uma hipótese que será testada através de ensaios de acoplamento entre o 20SPT-C221S e a unidade regulatória 19S comparativamente ao 20SPT selvagem. Por outro lado, talvez a diminuição do conteúdo de proteínas poli-ubiquitinadas na linhagem C76 seja consequência do mesmo fenômeno, ou seja, aumento de acoplamento entre unidade catalítica 20S e regulatória 19S uma vez que as formas fechadas do 20SPT nesta linhagem mostrou-se mais abundante.

\subsection{Análise proteômica}

Como não encontramos nenhum resultado que justifique o aumento do tempo de vida cronológico da linhagem C221, partimos então para uma análise proteômica na tentativa de encontrar alguma diferença entre a linhagem C221 e a selvagem. O nosso principal objetivo nesses ensaios foi identificar proteínas que apresente queda em sua concentração no extrato celular total. De forma especulativa, isso indicaria que o proteassomo com a mutação $\alpha 5$ C221S poderia estar degradando alguma proteína que esteja relacionada com a regulação negativa do tempo de vida cronológico. Assim sendo, procedemos com a separação do conteúdo de proteínas solúveis totais nas linhagens selvagem e C221. Dados representativos estão mostrados na figura 16.

Na figura 16 estão marcados os spots selecionados e cortados para a identificação proteica. Como podemos ver na tabela 5, foram identificadas algumas proteínas da via glicolítica, da fermentação alcoólica, do metabolismo de purinas, proteínas ribossomais e vários "spots" relativos a Hsp26 (9-12). Identificamos também uma proteína down-regulated relacionada indiretamente com a longevidade, a FKBP (FK506-binding protein 1). As FKBPs são proteína que interagem com drogas imunossupressoras como a Rapamicina formando complexos capazes de inibir a via de TOR (BROWN et al., 1994; HARRISON et al., 2009). 

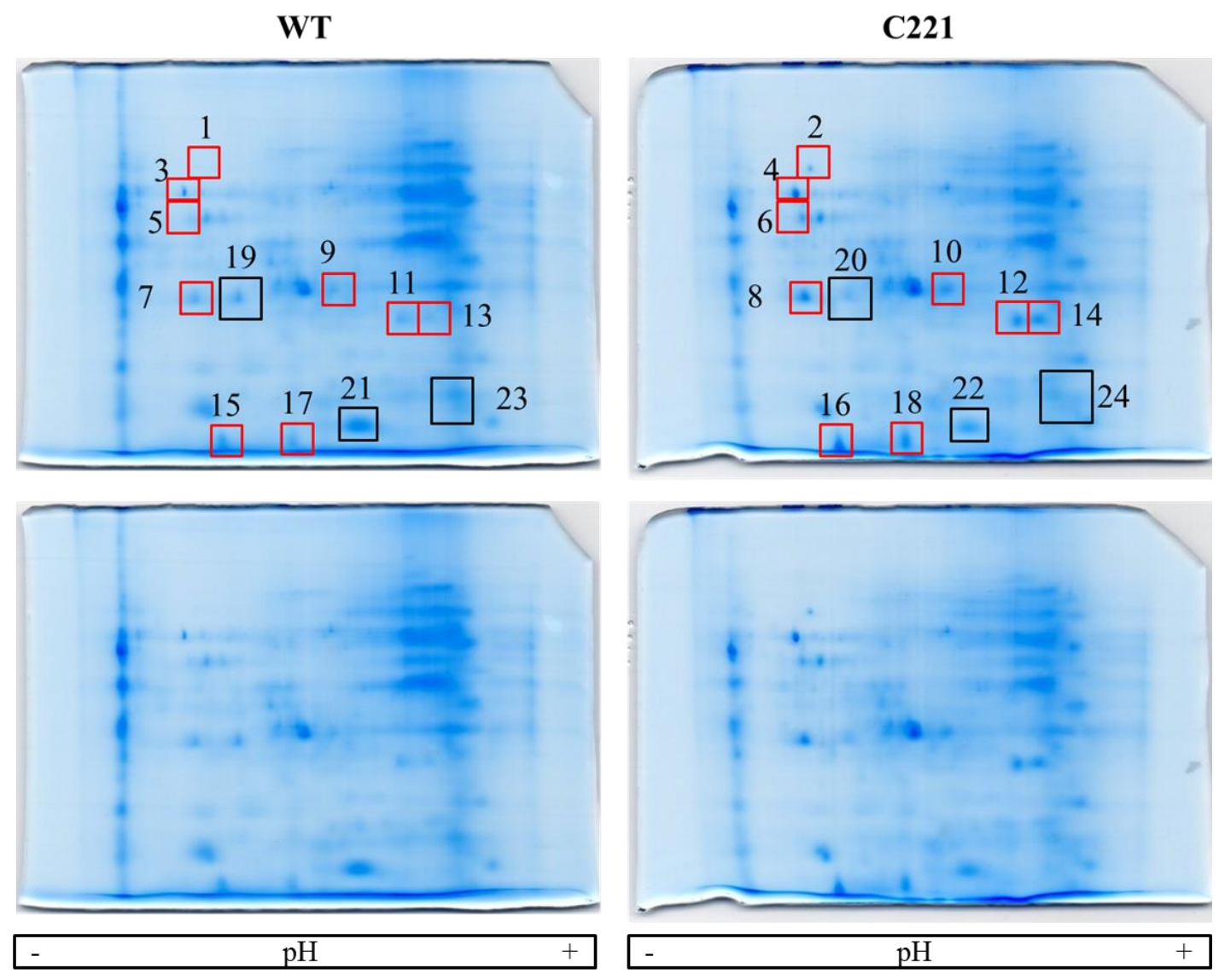

Figura 16 - Eletroforese bidimensional do extrato celular. Foram aplicadas $200 \mu \mathrm{g}$ de extrato celular total em tiras de gradiente de $\mathrm{pH}$ de 4-7, em seguida a tira foi colocada em gel SDS-PAGE 12,5\%. Os quadrados vermelhos indicam proteínas "up-regulated" e os quadrados pretos indicam proteínas "down-regulated" na linhagem C221. Os resultados mostrados são representativos de três experimentos independentes.

Tabela 5 - Expressão proteica diferencial no extrato celular das linhagens de Saccharomyces cerevisiae selvagem e na mutante C221.

\begin{tabular}{cccc}
\hline Spots & Cód. da Proteína & Proteína & Via Metabólica \\
\hline $\mathbf{1}$ & $*$ & $*$ & $*$ \\
$\mathbf{2}$ & P06169 & Piruvato descarboxilase isozima 1 & Fermentação alcoolica \\
$\mathbf{3}$ & P00925 & Enolase 2 & Glicólise \\
$\mathbf{4}$ & P00925 & Enolase 2 & Glicólise \\
$\mathbf{5}$ & P00925 & Enolase 2 & Glicólise \\
& P14540 & Frutose-bifosfato aldolase & Glicólise \\
$\mathbf{6}$ & P00925 & Enolase 2 & Glicólise \\
& P41770 & Frutose-bifosfato aldolase & Glicólise \\
$\mathbf{7}$ & P00942 & Triose fosfato isomerase & Gliconeogênese e Glicólise \\
& B3LG61 & Adenilato cinase & Metabolismo de purinas
\end{tabular}




\begin{tabular}{|c|c|c|c|}
\hline 8 & P00942 & Triosefosfato isomerase & Gliconeogênese e Glicólise \\
\hline 9 & P15992 & Hsp26 & Proteína de choque térmico \\
\hline 10 & P15992 & Hsp26 & Proteína de choque térmico \\
\hline 11 & P15992 & Hsp26 & Proteína de choque térmico \\
\hline 12 & P15992 & Hsp26 & Proteína de choque térmico \\
\hline 13 & $*$ & $*$ & $*$ \\
\hline 14 & $*$ & $*$ & $*$ \\
\hline 15 & P00925 & Enolase 2 & Glicólise \\
\hline \multirow[t]{2}{*}{16} & P00925 & Enolase 2 & Glicólise \\
\hline & P00560 & Fosfoglicerato cinase & Glicólise \\
\hline \multirow[t]{2}{*}{17} & P00925 & Enolase 2 & Glicólise \\
\hline & P0C0V8 & Proteina ribossomal 40S S21-A & Síntese proteica \\
\hline 18 & P00924 & Enolase 1 & Glicólise \\
\hline 19 & P00942 & Triosefosfato isomerase & Gliconeogênese e Glicólise \\
\hline \multirow[t]{2}{*}{20} & P00943 & Triosefosfato isomerase & Gliconeogênese e Glicólise \\
\hline & P07170 & Adenilato cinase & Metabolismo de purinas \\
\hline 21 & P20081 & FKBP12 & Proteína de Ligação \\
\hline 22 & P20081 & FKBP12 & Proteína de Ligação \\
\hline \multirow[t]{6}{*}{23} & P0CX55 & Proteina ribossomal 40S S18-A & Síntese proteica \\
\hline & P05756 & Proteina ribossomal 40S S13 & Síntese proteica \\
\hline & P07280 & Proteina ribossomal 40S S19-A & Síntese proteica \\
\hline & P39938 & Proteina ribossomal 40S S26-A & Síntese proteica \\
\hline & Q01855 & Proteina ribossomal 40S S15 & Síntese proteica \\
\hline & P0C2H6 & Proteina ribossomal 60S L27-A & Síntese proteica \\
\hline \multirow[t]{3}{*}{24} & P0CX55 & Proteina ribossomal 40S S18-A & Síntese proteica \\
\hline & P07280 & Proteina ribossomal 40S S19-A & Síntese proteica \\
\hline & P39938 & Proteina ribossomal 40S S26-A & Síntese proteica \\
\hline
\end{tabular}

Os spots mostrados na Figura 17 foram digeridos e posteriormente analisados por espectrometria de massas de acordo com protocolos descritos em Materiais e Métodos. Os dados mostrados são a somatória de spots identificados nos três experimentos independentes. *Proteína não identificada

Devido à identificação da proteína FKPB, partimos para avaliar a resistência das linhagens a rapamicina por diluição seriada seguido de teste de spot. Constatamos maior sensibilidade a rapamicinadas nas linhagens mutantes (Figura 17), com isso vimos que o fato da selvagem apresentar mais FKBP não significa que ela possui mais rapamicina ativa e consequentemente maior sensilidade quando administrada essa droga. 
Controle

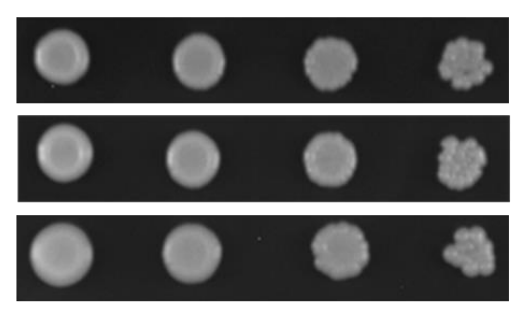

$50 \mathrm{ng}$

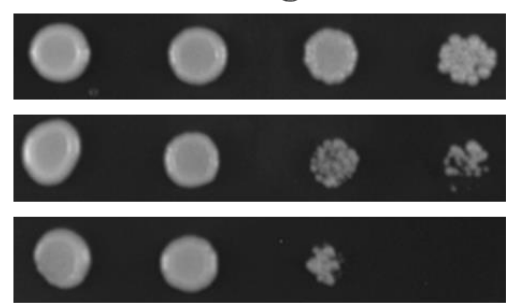

100ng

WT

C221

C76

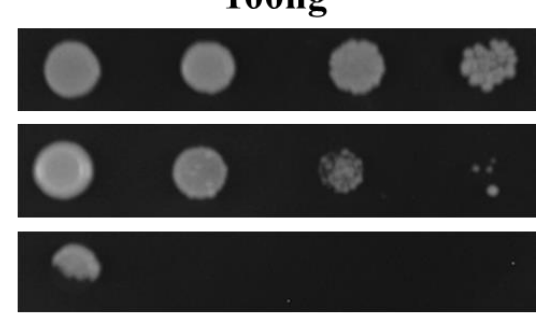

150ng

WT

C221

C76

Figura 17 - Análise da resistência a rapamicina das linahgens. As linhagens selvagem e mutantes C221 e C76 foram crescidas até a fase estacionária em meio YPD 4\% e então submetidas à diluição seriada, $5 \mu 1$ de cada diluição foi plaqueada em meio YPD sólido contendo diferentes concentrações de rapamicina. AS placas foram incubadas a $30{ }^{\circ} \mathrm{C}$ por 48 horas. A linhagem WT mostrou maior resistência ao composto. Os resultados mostrados são representativos de dois experimentos independentes realizados em duplicata. 


\section{DISCUSSÃO}

A S-glutatiolação do proteassomo $20 \mathrm{~S}$ tem sido interpretada como um mecanismo reversível que possibilita a remoção de proteínas não estruturadas e danificadas oxidativamente (SILVA et al., 2008). A reversibilidade deste processo, como anteriormente mostrada in vitro, seria feita por oxidoredutases, tais como a Grx 2 e Trx 1 e 2 (SILVA et al., 2008). Essa modificação pós-traducional promove a abertura da câmara catalítica do proteassomo 20S e comsequentemente um aumento da velocidade de degradação de proteínas (SILVA et al., 2012). A partir dos dados publicados previamente pelo nosso grupo (SILVA et al., 2012), onde identificou-se duas cisteínas glutatioláveis (Cys221 e Cys76) na subunidade $\alpha 5$ do proteassomo, construiu-se linhagens de levedura com mutações sítio-específicas ( $\alpha 5$ C221S e a5-C76S) com o intuito de avaliar a importância de cada Cys neste processo. Neste trabalho avaliamos incialmente as mudanças estruturais e funcionais do proteassomo $20 \mathrm{~S}$ e, posteriormente, as alterações fenotípicas causadas por esta mutação, além disso, avaliamos também os parâmetros redox dessas linhagens a fim de justificar as alterações fenotípicas observadas.

Dados obtidos por microscopia eletrônica de transmissão comprovam que os 20SPT com a mutação $\alpha 5-\mathrm{C} 221 \mathrm{~S}$ se encontram prevalentemente na forma aberta $(80 \% \pm 3)$ comparada a selvagem $(65 \% \pm 4)$, enquanto que o mutante $\alpha 5$-C76S $(30 \% \pm 2)$ apresenta-se prevalentemente na forma fechada (Figura 7). Essas modificações estruturais observadas são condizentes com as alterações na expectativa de vida e resistência ao estresse oxidativo observadas nessas linhagens. Avaliamos a atividade catalítica tipo-quimiotripsina (Cht-L) e a atividade proteolítica do proteassomo $20 \mathrm{~S}$ purificado dessas linhagens e observamos que o proteassomo com a mutação $\alpha 5-\mathrm{C} 221 \mathrm{~S}$ possui maior atividade proteolítica, ou seja, esse proteassomo apresentou um aumento da velocidade de degradação de proteínas não 
estruturadas e danificadas oxidativamente (Figura 9). Interpretamos esses resultados como uma consequência do aumento na abertura da câmara catalítica (Figura 7).

Avaliamos a capacidade de crescimento dessas linhagens, no qual a linhagem com a mutação a5-C221S apresentou um crescimento semelhante a selvagem, por outro lado, a linhagem C76 mostrou um crescimento em torno de $40 \%$ menor que as demais (Figura 1). Com a técnica de diluição seriada, analisamos a tolerância ao estresse oxidativo em diferentes concentrações de peróxido de hidrogênio, onde vimos maior resistência da linhagem C221 em comparação a selvagem. A linhagem C76 não apresentou sensibilidade ao peróxido de hidrogênio e sim uma dificuldade no crescimento, visto que o seu crescimento é bastante semelhante em todas as concentrações de $\mathrm{H}_{2} \mathrm{O}_{2}$ (Figura 2).

Inúmeros dados na literatura correlacionam a ativação do proteassomo com o aumento da longevidade de muitas espécies (CHONDROGIANNNI et al., 2015, KRUEGEL et al., 2011; TSAKIRI et al, 2013). Portanto, parece estar bem estabelecida a relação entre ativação do proteassomo e aumento da expectativa de vida. No entanto, os mecanismos bioquímicos/ moleculares desse fenômeno não são ainda conhecidos. Dessa forma, avaliamos o tempo de vida cronológico e replicativo das linhagens selvagem e mutantes. Em concordância com os dados da tolerância ao estresse oxidativo e da atividade catalítica, a linhagem mutante C221 apresentou maior tempo de vida cronológico, porém uma diminuição no tempo de vida replicativo em comparação a selvagem (Figura 3 e 4). Observamos também que a linhagem C76 possui claramente uma menor longevidade quando comparadas com as demais linhagens.

Uma vez que a linhagem C221 apresentou maior tempo de vida cronológico, fomos à busca de respostas que pudessem justificar esse aumento da longevidade cronológica. Com uma série de ensaios de imunomarcação, verificamos que não há diferenças significativas nas concentrações de anti-oxidantes analisadas entre as linhagens (Figura 10), em contrapartida, constatamos um aumento de proteínas poli-ubiquitinas na linhagem C221 e uma diminuição 
na linhagem C76 em ralação a selvagem (Figura 15). As proteínas poli-ubiquitinadas são reconhecidas e ligadas especificamente na unidade regulatória 19S para a degradação via proteassomo 26S (DEMASI et al., 2014; PETH et al., 2013). Esse aumento de proteínas poliubiquitinadas na linhagem C221 pode ser justificada devido à diminuição de degradação via proteassomo 26S, ou seja, essa linhagem possui em sua maioria formas abertas de proteassomo $20 \mathrm{~S}$ e consequentemente menor capacidade de se acoplar com a unidade regulatória 19S para formar o complexo 26S. Essa possibilidade ainda será avaliada por ensaios de acoplamento.

Outra diferença interessante relacionada ao metabolismo redox observada entre as linhagens foi o aumento significativo da razão GSH/GSSH nas linhagens mutantes. A razão GSH/GSSG é um dos fatores determinantes do estado redox intracelular (JONES et al., 2002; MELLO et al., 2013). O metabolismo de GSSG envolve ainda sua redução pela ação da enzima glutationa redutase (GR) que utiliza NADPH como equivalente redutor, recuperando o conteúdo de GSH. A diferença observada pode ser devido a menor concentração da glutationa total e não ao aumento de GSH (forma reduzida). Outra possibilidade seria o aumento da atividade de glutationa redutase (GR) nessas linhagens, porém observamos uma atividade semelhante entre as mutantes e, em relação a selvagem uma ligeira diminuição. Visto que o $\mathrm{H}_{2} \mathrm{O}_{2}$ tem papel central na geração de espécies reativas de oxigênio intracelularmente, analisamos a atividade de remoção de peróxido de hidrogênio $\left(\mathrm{H}_{2} \mathrm{O}_{2}\right)$ nessas linhagens (TOLEDANO et al, 2013). A linhagem C76S mostrou ligeiro aumento na capacidade de remover $\mathrm{H}_{2} \mathrm{O}_{2}$ quando comparada com a WT.

Sabendo que a formação intracelular de proteínas carboniladas representa a mais importante modificação oxidativa de proteínas (DEMASI et al., 2003; ERJAVEC et al., 2007), avaliamos o conteúdo intracelular de proteínas oxidadas através da imunomarcação com anti-DNP, no qual observamos uma maior formação de proteínas carboniladas em ambas 
linhagens mutantes quando comparadas a linhagem selvagem (Figura 12). Esse dado condiz com o dado de agregação proteica (Figura 13), onde detectamos um aumento de agregados proteicos na linhagem mutante C221. A formação e o acúmulo de agregados proteicos compromete toda homeostase celular e estão diretamente relacionados a diversas doenças neurodegenerativas e ao envelhecimento (BALCH et al., 2008; HIPP et al., 2014; KNOWLES et al., 2014; OLZSCHA et al., 2011). No entanto, estudos com C. elegans conduzidos por Walther et al., (2015) mostraram um aumento na formação de agregados associados a pequenas proteínas de choque térmico (small-heat shock proteins) na linhagem mutante de maior durabilidade (daf-2). A interpretação dos autores foi de que esses agregados ocorreram não apenas como consequência da diminuição da homeostase proteica, mas também como uma forma de "sequestro" de proteínas potencialmente prejudiciais e, as chaperonas S-Hsps teriam papel relevante no sequestro dessas proteínas. Esses dados coincidem com os nossos resultados, no qual constatamos maior formação de agregados na linhagem C221 de maior longevidade.

Buscando entender melhor o aumento do tempo de vida cronológico da linhagem mutante C221, partimos para a análise proteômica na tentativa de encontrar alguma diferença entre a linhagem C221 e a selvagem. O intuito dessa análise foi procurar alguma proteína diminuída apenas na linhagem C221. Especulamos que o proteassomo com a mutação $\alpha 5$ C221S poderia estar degradando alguma proteína que esteja relacionada com o aumento do tempo de vida cronológico. Dentre as proteínas identificadas (Tabela 5), interessantemente encontramos uma proteína relacionada indiretamente com longevidade, a FKBP. As FKBPs consistem de uma família de proteínas que possui atividade peptidilprolil isomerase cis-trans, trata-se de uma das principais imunofilinas que desempenham importantes papeis na ativação de células T (KANG et al., 2008; SHARMA et al., 1994). As FKBPs estão envolvidos em vários processos biológicos como: Dobramento/estabilidade proteica, sinalização celular, 
regulação gênica, transporte de proteínas e regulação epigenética de histonas e cromatina (BRILLANTES et al., 1994; LI et al., 2010; NELSON et al., 2006; XIAO et al., 2006). Essa proteína pode interagir com drogas imunossupressoras como a rapamicina formando complexos capazes de inibir a via de TOR de sinalização. (BROWN et al., 1994; GUDAVICIUS et al., 2013; HARRISON et al., 2009).

Esse dado nos levou a um teste comparativo em relação à resistência das linhagens selvagem e mutantes à rapamicina. Através da diluição seriada, observamos menor resistência a rapamicina nas linhagens mutantes (Figura 17). Considerando-se que a linhagem C221 apresenta menos conteúdo intracelular de FKBP e, portanto, maior sensibilidade à rapamicina, os resultados obtidos nesse ensaio são compatíveis com a hipótese de que poderia haver diferenças de mTOR nessa linhagem, ou seja, uma diminuição de mTOR na linhagem C221, visto que a inibição da via TOR acarreta em um aumento da longevidade cronológica de leveduras (LONGO et al., 2012). 


\section{CONCLUSÕES}

A caracterização fenotípica e bioquímica das linhagens da levedura $S$. cerevisiae com mutações sítio-específicas na subunidade $\alpha 5$ do proteassomo $20 \mathrm{~S}$ foram os principais objetivos desse trabalho. Dentre as principais conclusões, podemos citar:

- A mutação da Cys76 da subunidade $\alpha 5$ gerou uma linhagem com dificuldades de crescimento e queda significativa na expectativa de vida tanto cronológica quanto replicativa. Vale ressaltar que esse resíduo de Cys é altamente conservado na escala evolutiva: da levedura ao homem. Portanto, nos parece que a glutatiolação desse resíduo e, alterações anteriormente observadas e confirmadas neste trabalho sobre a abertura da câmera catalítica e aumento de atividade proteolítica, é uma modificação relevante na manutenção da proteostase intracelular.

- Diferentemente, a manutenção do resíduo Cys76 e mutação do resíduo a5-C221, resultou no aumento da longevidade celular coincidentemente com maior frequência de abertura da câmera catalítica do 20SPT observado nessa linhagem (Figura 7) e aumento da atividade proteolítica (Figura 9). Esses dados sugerem que a glutatiolação do resíduo C221 seja, na verdade, um regulador negativo da abertura da câmera sendo que sua mutação resulta numa estrutura mais eficiente para proteólise.

- O proteassomo com a mutação $\alpha 5-\mathrm{C} 221 \mathrm{~S}$ purificado da levedura crescida até a fase estacionária responde ao tratamento com DTT, isso indica que o resíduo Cys76 permanece glutatiolado.

- Uma vez que não houve alteração nas concentrações de enzimas anti-oxidantes entre as linhagens, concluímos que as alterações fenotípicas observadas (p.e., aumento da expectativa de vida da linhagem C221), não estão relacionadas ao estado redox dessas células, mas provavelmente, à maior eficiência catalítica do 20SPT. 


\section{REFERÊNCIAS*}

ARENDT, C. S.; HOCHSTRASSER, M. Identification of the yeast 20S proteasome catalytic centers and subunit interactions required for active-site formation. Proc. Natl. Acad. Sci. U.S.A., v. 94, p. 7156-7161, 1997.

BAUGH, J. M.; VIKTOROVA, E. G.; PILIPENKO, E. V. Proteasomes can degrade a significant proportion of cellular proteins independent of ubiquitination. J. Mol. Biol. v. 386, p. 814-827, 2009.

BERLETT, B. S.; STADTMAN, E. R. Protein oxidation in aging, disease, and oxidative stress. J. Biol. Chem., v. 272, n. 33, p. 20313-20316, 1997.

BIRBOIM, H. C.; DOLLY, J. A rapid alkaline extraction procedure for screening recombinant plasmid DNA. Nucleic Acids Res., v. 7, p. 1513-1523, 1979.

BOCHTLER, M., et al. The proteasome. Annu. Rev. Biophys. Biomol. Struct., v. 28, p. 295-317, 1999.

BOSE, S.; MASON, G. G.; RIVETT, A. J. Phosphorylation of proteasomes in mammalian cells. Mol. Biol. Rep., v. 26, p. 11-14, 1999.

BRILLANTES, A. B.; ONDRIAS, K.; SCOTT, A.; KOBRINSKY, E.; ONDRIASOVA, E.; MOSCHELLA, M. C.; JAYARAMAN, T.; LANDERS, M.; EHRLICH, B.E.; MARKS, A. R. Stabilization of calcium release channel (ryanodine receptor) function by FK506-binding protein. Cell, v. 77, p. 513-523,1994.

BROWN, E. J., ALBERS, M. W., SHIN, T. B., ICHIKAWA, K., KEITH, C.T., LANE, W.S.; SCHREIBER, S. L. A mammalian protein targeted by G1-arresting rapamycin-receptor complex. Nature, v. 369, p. 756-758, 1994.

BUTTERFIELD, D. A.; ABDUL, H. M.; NEWMAN, S.; REED, T. Redox proteomics in some age-related neurodegenerative disorders or models thereof. NeuroRx., v. 3, p. 344-357, 2006.

CARRARD, G.; DIEU, M.; RAES, M.; TOUSSAINT, O.; FRIGUET, B. Impact of ageing on proteasome structure and function in human lymphocytes. Int J Biochem Cell Biol., v. 35, p. 728-739, 2003.

\footnotetext{
*De acordo com:

ASSOCIAÇÃO BRASILEIRA DE NORMAS TÉCNICAS. NBR 6023: informação e documentação: referências: elaboração. Rio de Janeiro, 2002.
} 
COSTA, V.; QUINTANILHA, A.; MORADAS-FERREIRA, P. Protein oxidation, repair mechanisms and proteolysis in Saccharomyces cerevisiae. IUBMB Life, v. 59, p. 293-298, 2007.

COUX, O.; TANAKA, K., GOLDBERG, A. L. Structure and functions of the 20S and 26S proteasomes. Annu. Rev. Biochem., v. 65, p. 801-847, 1996.

CUNHA, F. M.; DEMASI, M.; KOWALTOWSKI, A. J. Aging and calorie restriction modulate yeast redox state, oxidized protein removal, and the ubiquitin-proteasome system. Free Radic Biol Med., v. 1;51, n. 3, p. 664-670, 2011.

DAHLMANN, B. Role of proteasomes in disease. BMC Biochem., v. 8, p. Suppl 1:S3, 2007.

DAVIES, K. J. A. Oxidative Stress, Antioxidant Defenses, and Damage Removal, Repair, and Replacement Systems., Life, v. 50, p. 279-289, 2000.

DAVIES, K. J. Degradation of oxidized proteins by the 20 S proteasome. Biochimie, v. 83, p. 301-310, 2001.

DAVIES, K. J.; SHRINGARPURE, R. Preferential degradation of oxidized proteins by the $20 \mathrm{~S}$ proteasome may be inhibited in aging and in inflammatory neuromuscular diseases. Neurology, v. 66, p. 93-96, 2006.

DEMASI, M.; NETTO, L. E.; SILVA, G. M.; HAND, A.; OLIVEIRA, C. L.; BICEV, R. N.; GOZZO, F.; BARROS, M. H.; LEME, J. M.; OHARA, E. Redox regulation of the proteasome via S-glutathionylation. Redox Biol., v. 2, p. 44-51, 2014.

DEMASI, M.; SHRINGARPURE, R.; DAVIES, K. J. Glutathiolation of the proteasome proteolytic inhibitors. Arch Biochem Biophys., v. 389, p. 254-263, 2001.

DEMASI, M.; SILVA, G. M.; NETTO, L. E. $20 \mathrm{~S}$ proteasome from Saccharomyces cerevisiae is responsive to redox modifications and is S-glutathionylated. J Biol Chem., v. 278, p. 679-685, 2003.

DI NOTO, L.; WHITSON, L. J.; CAO, X.; HART, P. J.; LEVINE, R. L. Proteasomal Degradation of Mutant Superoxide Dismutases Linked to Amyotrophic Lateral Sclerosis. J Biol Chem., v. 280, p. 39907-39913, 2005

DICK, T. P.; NUSSBAUM, A. K.; DEEG, M.; HEINEMEYER, W.; GROLL, M.; SCHIRLE, M.; KEIlHOLZ, W.; STEVANOVIC, S.; WOLF, D. H.; HUBER, R.; DIETZ, K.; RAMMENSEE, H. G.; SCHILD, H. Contribution of proteasomal beta-subunits to the cleavage of peptide substrates analyzed with yeast mutants. J. Biol. Chem., v. 273, p. 2563725646, 1998. 
DUNLOP, R. A.; BRUNK, U. T.; RODGERS, K. J. Oxidized proteins: mechanisms of removal and consequences of accumulation. IUBMB Life, v. 61, p. 522-527, 2009.

ESCUSA-TORET, S., VONK, W.I., AND FRYDMAN, J. Spatial sequestration of misfolded proteins by a dynamic chaperone pathway enhances cellular fitness during stress. Nat Cell Biol., v. 15, p. 1231-1243, 2013.

ERJAVEC, N.; LARSSON, L.; GRANTHAM, J.; NYSTRÖM, T. Accelerated aging and failure to segregate damaged proteins in Sir2 mutants can be suppressed by overproducing the protein aggregation-remodeling factor Hsp104p. Genes Dev., v. 21 (19), p. 2410-2421, 2007.

FERRINGTON, D. A.; SUN, H.; MURRAY, K. K.; COSTA, J.; WILlIAMS, T. D.; BIGELOW, D. J.; SQUIER, T. C. Selective degradation of oxidized calmodulin by the $20 \mathrm{~S}$ proteasome. J Biol Chem., v. 276, p. 937-943, 2001.

FINLEY, D. Recognition and processing of ubiquitin-protein conjugates by the proteasome. Annu. Rev. Biochem., v. 78, p. 477-513, 2009.

GALLOGLY, M. M.; MIEYAL, J. J. Mechanisms of reversible protein glutathionylation in redox signaling and oxidative stress. Current Opinion in Pharmacology, v. 7, p. 381-391, 2007.

GIULIVI, C.; PACIFICI, R. E.; DAVIES, K. J. Exposure of hydrophobic moieties promotes the selective degradation of hydrogen peroxide-modified hemoglobin by the multicatalytic proteinase complex, proteasome. Arch. Biochem. Biophys., v. 311, n. 2, p. 329-341, 1994.

GLICKMAN, M. H.; RUBIN, D. M.; FRIED, V. A.; FINLEY, D. The regulatory particle of the Saccharomyces cerevisiae proteasome. Mol. Cell. Biol., v. 18, p. 3149-3162, 1998.

GOMES, A. V.; ZONG.,C.; EDMONDSON, R. D.; LI, X.; STEFANI, E.; ZHANG, J.; JONES, R. C.; THYPARAMBIL, S.; WANG, G. W.; QIAO, X., BARDAG-GORCE, F.; PING, P. Mapping the murine cardiac 26S proteasome complexes. Circ. Res., v. 99, p. 362371, 2006.

GROLL, M.; HEINEMEYER, W.; JAGER, S.; ULLRICH, T.; BOCHTLER, M.; WOLF, D. H.; HUBER, R. The catalytic sites of 20 S proteasomes and their role in subunit maturation: a mutational and crystallographic study. Proc. Natl. Acad. Sci. U.S.A., v. 96, p. 10976-10983, 1999.

GUDAVICIUS, G.; SOUFARI, H.; UPADHYAY, S. K.; MACKERETH, C. D.; NELSON, C. J. Resolving the functions of peptidylprolyl isomerases: insights from the mutagenesis of the nuclear FKBP25 enzyme. Biochem. Soc. Trans., v. 41, n. 3, p. 761-768, 2013. 
HARRISON，D. E.;STRONG，R.; SHARP，Z. D.; NELSON, J. F.; ASTLE, C. M.; FLURKEY, K.; NADON, N. L.; WILKINSON, J. E.; FRENKEL, K.; CARTER, C. S.; PAHOR, M.; JAVORS, M. A.; FERNANDEZ, E.; MILLER, R. A. Rapamycin fed late in life extends lifespan in genetically heterogeneous mice. Nature, v. 460, p. 392-395, 2009.

HEINEMEYER, W., et al. The active sites of the eukaryotic $20 \mathrm{~S}$ proteasome and their involvement in subunit precursor processing. J. Biol. Chem., v. 272, p. 25200-25209, 1997.

HERSHKO, A.; CIECHANOVER, A.; VARSHVSHY, A. Basic Medical Research Award. The ubiquitin system. Nat. Med., v. 6, p. 1073 - 1081, 2000.

HIPP, M. S.; PARK, S. H.; HARTL, F. U. Proteostasis impairment in protein-misfolding and -aggregation diseases. Trends Cell Biol., v. 24, p. 506-514, 2014.

HIRSCH, C.; PLOEGH, H.L. Intracellular targeting of the proteasome. Trends Cell Biol., v. 10, n. 7, p. 268-272, 2000.

HOFFMAN, L.; RECHSTEINER, M. Nucleotidase activities of the $26 \mathrm{~S}$ proteasome and its regulatory complex. J. Biol. Chem., v. 271, p. 32538-32545, 1996.

INAI, Y.; NISHIKIMI, M. Increased degradation of oxidized proteins in yeast defective in 26S proteasome assembly. Arch. Biochem. Biophys., v. 404, p. 279-284, 2002.

IWAFUNE, Y.; KAWASAK, I. H.; HIRANO, H. Electrophoretic analysis of phosphorylation of the yeast 20S proteasome. Electrophoresis, v. 23, p. 329-338, 2002.

JONES, D. P. Redox potential of GSH/GSSG couple: assay and biological significance. Methods Enzymol., v. 348, p. 93-112, 2002.

JUNG, T.; BADER, N.; GRUNE, T. Oxidized proteins: Intracellular distribution and recognition by the proteasome. Arch Biochem Biophysics., v. 462, p. 231-237, 2007

JUNG, T.; CATAlGOL, B.; GRUNE, T. The proteasomal system. Mol Aspects Med., v. 30, p. 191-296, 2009.

KANG, C. B.; HONG, Y.; DHE-PAGANON, S.; YOON, H. S. FKBP family proteins: immunophilins with versatile biological functions. Neurosignals, v. 16, n. 4, p. 318-325, 2008.

KIKUCHI, J.; IWAFUNE, Y.; AKIYAMA, T.; OKAYAMA, A.; NAKAMURA, H.; ARAKAWA, N.; KIMURA, Y.; HIRANO, H. Co- and post-translational modifications of the 26S proteasome in yeast. Proteomics, v.10, n. 15, p. 2769-7279, 2010. 
KNECHT, E., et al. Intracellular protein degradation in mammalian cells: recent Developments. Cell. Mol. Life Sci., v. 66, p. 2427-2443, 2009.

KNOWLES, T. P.; VENDRUSCOLO, M.; DOBSON, C. M. The amyloid state and its association with protein misfolding diseases. Nat. Rev. Mol. Cell Biol., v. 15, p. 384-396, 2014.

KOPLIN, A.; PREISSLER, S.; ILINA, Y.; KOCH, M.; SCIOR, A.; ERHARDT, M.; DEUERLING, E. A dual function for chaperones SSB-RAC and the NAC nascent polypeptide-associated complex on ribosomes. J. Cell Biol. v. 189, n. 1, p. 57-68, 2010.

KOPP, F.; HENDIL, K. B.; DAHLMANN, B.; KRISTENSEN, P.; SOBEK, A.; UERKVITZ, W. Subunit arrangement in the human 20S proteasome. Proc. Natl. Acad. Sci. U.S.A., v. 94, p. 2939-2944, 1997.

KRUEGEL, U.; ROBISON, B.; DANGE, T.; KAHLERT, G.; DELANEY, J. R.; KOTIREDDY, S.; TSUCHIYA, M.; TSUCHIYAMA, S.; MURAKAMI, C. J.; SCHLEIT, J.; SUTPHIN, G.; CARR, D.; TAR, K.; DITTMAR, G.; KAEBERLEIN, M.; KENNEDY, B. K.; SCHMIDT1, M. Elevated Proteasome Capacity Extends Replicative Lifespan in Saccharomyces cerevisiae. PLos Genet., v. 7, N. 9, p. e1002253, 2011.

LI, H.; LUAN, S. AtFKBP53 is a histone chaperone required for repression of ribosomal RNA gene expression in Arabidopsis. Cell Res., v. 20, p. 357-366, 2010.

LIU, C. W.; LI, X.; THOMPSON, D.; WOODING, K.; CHANG, T. L.; TANG, Z.; YU, H.; HOMAS, P. J.; DEMARTINO, G. N. ATP binding and ATP hydrolysis play distinct roles in the function of 26S proteasome. Mol. Cell., v. 24, p. 39-50, 2006.

LONGO, V. D.; SHADEL, G. S.; KAEBERLEIN, M.; KENNEDY, B. Replicative and Chronological Aging in Saccharomyces cerevisiae. Cell Metab., v. 16, n. 1, p. 18-31, 2012.

LÖWE, J.; STOCK, D.; JAP, B.; ZWICKL, P.; BAUMEISTER, W.; HUBER, R. Crystal structure of the $20 \mathrm{~S}$ proteasome from the archaeon $T$. acidophilum at 3.4 A resolution. Science, v. 268, p. 533-539, 1995.

MA, B.; ZHANG, K.; HENDRIE, C.; LIANG, C.; LI, M.; DOHERTY-KIRBY, A.; LAJOIE, G. PEAKS: Powerful Software for Peptide De Novo Sequencing by MS/MS. Rapid Communications in Mass Spectrometry, v. 17, n. 20, p. 2337-2342, 2003.

MATSUDA, N.; TANAKA, K. Does impairment of the ubiquitin-proteasome system or the autophagy-lysosome pathway predispose individuals to neurodegenerative disorders such as Parkinson's disease? J Alzheimers Dis., v. 19, p. 1-9, 2010. 
MONTAGUT, C.; ROVIRA, A.;ALBANELL, J. The proteasome: a novel target for anticancer therapy. Clin. Transl. Oncol., v. 8, p. 313-317, 2006

MUNHOZ, D. C.; NETTO, L. E. S. Cytosolic Thioredoxin Peroxidase I and II Are Important Defenses of Yeast against Organic Hydroperoxide Insult. J Biol Chem., v. 279, p. 3521935227, 2004.

NAVON, A.; GOLDBERG, A. L. Proteins are unfolded on the surface of the ATPase ring before transport into the proteasome. Mol. Cell., v. 8, p. 1339-1349, 2001.

NELSON, C.J.; SANTOS-ROSA, H.; KOUZARIDES, T. Proline isomerization of histone H3 regulates lysine methylation and gene expression. Cell, v. 126, p. 905-916, 2006.

NUSSBAUM, A. K.; DICK, T. P.; KEILHOLZ, W.; SCHIRLE, M.; STEVANOVIC, S.; DIETZ, K.; HEINEMEYER, W.; GROLL, M.; WOLF, D. H.; HUBER, R.; RAMMENSEE, H. G.; SCHILD, H. Cleavage motifs of the yeast 20S proteasome beta subunits deduced from digests of enolase 1. Proc. Nat.l Acad. Sci. U.S.A., v. 95, p. 12504-12509, 1998.

OLIVEIRA, G, A.; TAHARA, E. B.; GOMBERT, A. K.; BARROS, M. H.; KOWALTOWSKI, A. J. Increased aerobic metabolism is essential for the beneficial effects of caloric restriction on yeast life span. J. Bioenerg. Biomembr., v. 40, p. 381-388, 2008.

OLZSCHA, H.; SCHERMANN, S. M.; WOERNER, A. C.; PINKERT, S.; HECHT, M. H.; TARTAGLIA, G. G.; VENDRUSCOLO, M.; HAYER-HARTL, M.; HARTL, F. U.; VABULAS, R. M. Amyloid-like aggregates sequester numerous metastable proteins with essential cellular functions. Cell, v. 144, p. 67-78, 2011.

PACIFICI, R. E.; DAVIES K. J. A. Protein degradation as an index of oxidative stress. Methods. Enzymol., v. 186, p. 485-502, 1990.

PACIFICI, R. E.; KONO, Y.; DAVIES, K. J. Hydrophobicity as the signal for selective degradation of hydroxyl radical-modified hemoglobin by the multicatalytic proteinase complex proteasome. J. Biol. Chem., v. 268, p. 15405-15411, 1993.

PALMER, A.; RIVETT, A. L.; THOMSON, S.; HENDIL, K. B.; BUTCHER, G. W.; FUERTES, G.; KNECHT, E.. Subpopulations of proteasomes in rat liver nuclei, microsomes and cytosol. Biochem J., v. 316, p. 401-407, 1996.

PERKINS, D. N.; PAPPIN, D. J. C.; CREASY, D. M.; COTTRELL, J. S. Probability-based protein identification by searching sequence databases using mass spectrometry data. Electrophoresis, v. 20, p. 3551-3567, 1999.

PETRUCELLI, L; DAWSON, T. M. Mechanism of neurodegenerative disease: role of the ubiquitin proteasome system. Ann. Med. v. 36, p. 315-320, 2004. 
PICKART, C. M.; COHEN, R. E.; Proteasomes and their kin: proteases in the machine age. Nat. Rev. Mol. Cell Biol., v. 5, p. 177-187, 2004.

PICKERING, A. M.; DAVIES, K. J. Degradation of Damaged Proteins - The Main Function of the 20S Proteasome. Prog. Mol. Transl. Sci., v. 109, p. 227-248, 2012.

RAKHIT, R.; CROW, J. P.; LEPOCK, J. R.; KONDEJEWSKI, L. H.; CASHMAN, N. R.; CHAKRABARTTY, A. Monomeric Cu,Zn-superoxide Dismutase Is a Common Misfolding Intermediate in the Oxidation Models of Sporadic and Familial Amyotrophic Lateral Sclerosis. J. Biol. Chem., v. 279, p. 15499-15504, 2004.

RIVETT, A. J.; PALMER, A. \& KNECHT, E. Electron microscopic localization of the multicatalytic proteinase complex in rat liver and in cultured cells. J Histochem Cytochem., v. 40, p. 1165-1172, 1992.

RIVETT, A. J. The multicatalytic proteinase: Multiple proteolytic activities. J Biol Chem., v. 264, n. 21, p. 12215-12219, 1989.

ROSE, M. D.; WINSTON, F. D.; HIETER, P. Methods in Yeast Genetics: A Laboratory Course Manual. New York: Cold Spring Harbor Laboratory Press, 1990. 198 p.

ROTHSTEIN, R. J. One step gene disruption in yeast. Methods Enzymol., v. 101, p. 202$211,1983$.

SCHIESTL, R. H.; GIETZ, R. D. High efficiency transformation of intact yeast cells using single stranded nucleic acid as a carrier. Curr. Genet., v. 16, p. 339-346, 1989.

SCHLESINGER, D. H.; GOLDSTEIN, G.; NIALL, H. D. The complete amino acid sequence of ubiquitin, an adenylate cyclase stimulating polypeptide probably universal in living cells. Biochemistry., v. 14, p. 2214-2218, 1975.

SHACTER, E.; WILLIANS, J. A.; LIM, M.; LEVINE, R. L. Differential susceptibility of plasma proteins to oxidative modification: examination by western blot immunoassay. Free Radic Biol Med., v. 17, n. 5, p. 429-437, 1994.

SHARMA, V. K.; LI, B.; KHANNA, A.; SEHAJPAL, P. K.; SUTHANTHIRAN, M. Which way for drug-mediated immunosuppression? Curr. Opin. Immunol., v. 6, p. 784-790, 1994.

SHELTON, M.D.; MIEYAL, J. J. Regulation by reversible S-glutathionylation: molecular targets implicated in inflammatory diseases. Mol Cells., v. 25, n. 3, p. 332-346, 2008.

SHERMAN, F.; HICKS, J. Micromanipulation and dissection of asci. Methods Enzymol., v. 194, p. 21-37, 1991. 
SHRINGARPURE, R. et al. Ubiquitin conjugation is not required for the degradation of oxidized proteins by proteasome. J. Biol. Chem., v. 278, p. 311-318, 2003.

SHRINGARPURE, R.; GRUNE, T.; DAVIES, K. J. A. Protein oxidation and $20 \mathrm{~S}$ proteasome-dependent proteolysis in mammalian cells. Cell. Mol. Life Sci., v. 58, p. 1442 1450, 2001.

SHRINGARPURE, R.; GRUNE, T.; MEHLHASE, J.; DAVIES, K. J. Ubiquitin conjugation is not required for the degradation of oxidized proteins by proteasome. J. Biol. Chem. v. 278, n. 1, p. 311-318, 2002.

SIES, H. Glutathione and its role in cellular functions. Free Radic Biol Med., v. 27, p. 916921, 1999.

SILVA, G. M.; NETTO, L. E.; DISCOLA, K. F.; PIASSA-FILHO, G. M.; PIMENTA, D.C.; BÁRCENA, J. A. e DEMASI, M. Role of glutaredoxin 2 and cytosolic thioredoxins in cysteinyl-based redox modification of the 20S proteassomo. FEBS J., v. 275, p. 2942-2955, 2008.

SILVA, G. M.; NETTO, L. E.; SIMÕES, V.; SANTOS, L. F. A.; GOZZO, F. C.; DEMASI, M. A. A.; OLIVEIRA, C. L. P.; BICEV, R. N.; Klitzke, C. F.; SOGAYAR, M. C. e DEMASI, M. Redox Control of 20S Proteasome Gating. Antiox Redox Signal v. 16, p. 1186-1193, 2012.

STADTMAN, E.R. Protein oxidation and aging. Free Radic Res., v. 40, p. 1250-8, 2006.

TAHARA, E. B.; BARROS, M. H.; OLIVEIRA, G, A.; NETTO, L. E.; KOWALTOWSKI, A. J. Dihydrolipoyl dehydrogenase as a source of reactive oxygen species inhibited by caloric restriction and involved in Saccharomyces cerevisiae aging. FASEB J. v. 21, p. 274-283, 2007.

TANAKA, K. Molecular biology of proteasomes. Mol Biol Rep., v. 21, n. 1, p. 21-26, 1995.

TANAKA, K. Molecular biology of the proteasome. Biochem Biophys Res Commun., v. 247, n. 3, p. 537-541, 1998.

TANAKA, K. The proteasome: Overview of structure and functions. Proc. Jpn. Acad. Ser. B., v. 85, p. 12-36, 2009.

TSAKIRI, E. N.; SYKIOTIS, G. P.; PAPASSIDERI, I. S.; GORGOULIS, V. G.; BOHMANN, D.; TROUGAKOS, I. P. Differential regulation of proteasome functionality in reproductive vs. somatic tissues of Drosophila during aging or oxidative stress. FASEB J. v. 27, n. 6, p. 2407-2420, 2013. 
ULLRICH, O.; REINHECKEL, T.; SITTE, N.; GRUNE, T.; DAVIES, K. J. Poly-ADP ribose polymerase activates nuclear proteasome to degrade oxidatively damaged histones. Proc Natl Acad Sci U S A., v. 96, n. 11, p. 6223-6228, 1999.

VARSHAVSKY, A. Regulated protein degradation. Trends Biochem. Sci., v. 30, p. 283$286,2005$.

VOGES, D.; ZWICKL, P.; BAUMEISTER, W. The 26S proteasome: a molecular machine designed for controlled proteolysis. Annu. Rev. Biochem., v. 68, p. 1015-68, 1999.

WALTHER, D. M.; KASTURI, P.; ZHENG, M.; PINKERT, S.; VECCHI, G.; CIRYAM, P.; MORIMOTO, R.; DOBSON, C. M.; VENDRUSCOLO, M.; MANN, M.; HARTL, F. U. Widespread Proteome Remodeling and Aggregation in Aging C. elegans. Cell, v. 161, n. 4, p. 919-932, 2015.

WEISSMAN, A. M. Themes and variations on ubiquitylation. Nat Rev Mole Cell Bio., v. 2, p. 169-178, 2001.

WeStermeIER, R; NAVEn, T. Proteomics in Practice. Weinheim: Wiley-VCH, 2002. $502 \mathrm{p}$.

WIGley, W. C.; FABUNMI, R. P.; LEE, M. G.; MARINO, C. R.; MUALlEM, S.; DEMARTINO, G. N.; THOMAS, P. J. Dynamic association of proteasomal machinery with the centrosome. J Cell Biol., v. 145, p. 481-490, 1999.

WILKINSON, K. D.; URBAN, M. K.; HAAS, A. L. Ubiquitin is the ATP-dependent proteolysis factor I of rabbit reticulocytes. J Biol Chem., v. 255, p. 7529-7532, 1980.

XIAO, H.; JACKSON, V.; LEI, M. The FK506-binding protein, Fpr4, is an acidic histone chaperone. FEBS Lett., v. 580, p. 4357-4364, 2006.

ZONG, C.; YOUNG, G. W.; WANG, Y.; LU, H.; DENG, N.; DREWS, O.; PING, P. Twoimensional electrophoresisbased characterization of post-translational modifications of mammalian 20S proteasome complexes. Proteomics, v. 8, p. 5025-5037, 2008. 